WP 44_13

\author{
Ehsan U. Choudhri \\ Carleton University, Canada
}

Lawrence L. Schembri

Bank of Canada, Canada

The Rimini Centre for Economic Analysis (RCEA), Italy

\title{
A Tale of Two Countries and Two BOOMS, CANADA AND THE UNITED STATES IN THE 1920S AND THE 2000S: THE ROLES of Monetary AND Financial STABILITy POLICIES
}

Copyright belongs to the author. Small sections of the text, not exceeding three paragraphs, can be used provided proper acknowledgement is given.

The Rimini Centre for Economic Analysis (RCEA) was established in March 2007. RCEA is a private, nonprofit organization dedicated to independent research in Applied and Theoretical Economics and related fields. RCEA organizes seminars and workshops, sponsors a general interest journal The Review of Economic Analysis, and organizes a biennial conference: The Rimini Conference in Economics and Finance (RCEF) . The RCEA has a Canadian branch: The Rimini Centre for Economic Analysis in Canada (RCEACanada). Scientific work contributed by the RCEA Scholars is published in the RCEA Working Papers and Professional Report series.

The views expressed in this paper are those of the authors. No responsibility for them should be attributed to the Rimini Centre for Economic Analysis. 


\title{
A Tale of Two Countries and Two Booms, Canada and the United States in the 1920s and the 2000s: The Roles of Monetary and Financial Stability Policies
}

\author{
Ehsan U. Choudhri \\ Carleton University \\ Lawrence L. Schembri \\ Bank of Canada
}

14 April 2013

\begin{abstract}
The paper examines the experience of Canada and the United States in the run-up to the two biggest financial crises in global history, in the 1920s and 2000s, and the roles of their monetary and financial stability policies. Comparing the Canadian and the U.S. experiences over the two periods is instructive because Canadian monetary policy was somewhat more conservative than U.S. monetary policy and there were important institutional differences in the two periods: Canada did not have a central bank in the 1920's and followed different financial stability policies in the 2000's. We present evidence that suggests two conclusions. Firstly, a more moderate Canadian monetary policy in the two booms affected Canada's relative macroeconomic performance during the booms; in particular, the extent of the economic expansion was less. Secondly, this difference, however, by itself, does not explain why Canada fared better in the recent crisis, but not in the Great Depression. Indeed, the comparative evidence suggests that it was the difference in the effectiveness of financial stability policies, primarily financial regulation supervision with respect to banks and housing finance, that explains the better Canadian performance during the recent crisis. In contrast, in the 1920s, both countries lacked the financial policies to control excess credit growth and both suffered as a consequence. In addition, both countries made policy mistakes in aftermath of the stock market crash and credit collapses; in particular, Canada pursued inflexible interest and exchange rate policies that aggravated the economic downturn.
\end{abstract}

The authors would like to thank Michael Bordo, Owen Humpage, David Laidler, Bennett McCallum, Eugene White and participants at the conference Current Policy under the Lens of Economic History at the Cleveland Federal Reserve Bank in December 2012 for their helpful comments and Janet Pass for superb research assistance. The views expressed in this paper reflect those of the authors not the Bank of Canada. 


\section{Introduction}

Financial crises offer an important opportunity for learning lessons, deepening understanding and improving policies. In this vein, this paper examines the experience of Canada and the United States in the run-up to the two biggest financial crises in global history, in the 1920s and 2000s, and the roles of their central banks. The central bank policy we focus on is monetary policy, but we also consider a broader set of policies that would fall under the heading of "financial stability” policy, which may not be exclusively the purview of the central bank. In this context, the goal of financial stability policy would be to limit systemic risk stemming from procyclical movements in credit, leverage and asset prices, which would render the financial system and the real economy more vulnerable to an adverse shock.

Canada and the United States experienced a similar boom-bust economic cycle in the 1920s and 1930s and 2000s. Although this occurrence is perhaps not surprising given the close economic and financial relationships between the two countries, they did have very different institutional frameworks for determining monetary and financial conditions over the two periods. In the 1920’s, the United States had a central bank, the Federal Reserve, that was primarily responsible for setting monetary conditions, whereas Canada was still in an era of free banking, where note issue and control of monetary conditions was primarily in the hands of the private commercial banks, although the Canadian Ministry of Finance did provide access to a lending window. In the 2000s, the Bank of Canada (BoC) followed an explicit inflation targeting rule, whereas the Federal Reserve (Fed) had a dual inflation and employment mandate. Both countries had limited micro and macroprudential financial regulation and supervision in 1920s, which was greatly 
strengthened in the 1930s in the aftermath of the crisis. ${ }^{1}$ In contrast, in the years before the most recent crisis, Canada stepped up its financial regulation and supervision, whereas the United States deregulated. ${ }^{2}$ The recently adopted Dodd-Frank Act, which includes the Volcker rule restricting the capital market activities of deposit-insured banks, undoes some of the recent deregulation and parallels the sweeping financial reforms of the 1930s.

In view of these institutional differences, comparing the Canadian experience to the U.S. experience over both periods is instructive for three reasons. Firstly, during both periods, Canadian monetary policy was somewhat more conservative than U.S. monetary policy and it would be useful to consider the relative economic impact. Secondly, Canada did not have a central bank in the 1920s; thus, the interesting question is whether this institutional difference led to different monetary conditions over this period. Finally, while both countries suffered the consequences of inadequate financial regulation and supervision in the first period, their experiences during the most recent crisis were very different, and it would be useful to consider the impact of these policies on the credit, asset price and economic booms.

Recently, there has been much debate about the causes of the recent economic boom (reflected especially in housing prices) that lead to the financial crisis of 2008 in the United States. Taylor (2008, 2012) has argued that easy U.S. monetary policy was largely responsible for the boom.

\footnotetext{
${ }^{1}$ In the United States, the Glass-Steagall Act of 1933, the Securities Act of 1933 and the Securities Exchange Act of 1934 were passed. Pecora (1939) provides further details on the investigations leading to these pieces of legislation. In Canada, the Macmillan Commission report (1933) recommended numerous reforms including the founding of the Bank of Canada in 1935. See Table 2 for more information.

${ }^{2}$ In Canada, in the wake of two small regional bank failures in 1983, the Northland Bank of Canada and the Canadian Commercial Bank, the Estey Commission Report (1986) recommended the creation of the Office of the Superintendent of Financial Institutions with a stronger mandate and increased independence. Inter-agency micro and macroprudential senior level agencies, including the Financial Institutions Supervisory Committee (FISC), the Senior Advisory Committee (SAC) and the Heads of Agencies (HOA) have also been established. See Financial Stability Board (2012) for more details. In the United States, the Angelides Commission Report (2011, p. xviii) on the financial crisis concluded "More than 30 years of deregulation and reliance on self-regulation by financial institutions ...had stripped away key safeguards, which could have helped avoid catastrophe”. See Table 3 for more information.
} 
He shows that the Fed lowered the interest rates to levels that were significantly below the path predicted by monetary policy rules that were followed since mid 1980's. Bernanke (2010) counters that one reason for the interest rate deviation from the rule was that inflation rates in this period turned out to be higher than the Fed's forecasts. Another reason was the concern that interest rates were headed towards zero bound and that aggressive policy action was needed to avoid this situation. He also presents some evidence indicating that the monetary policy did not cause the housing boom, but rather the housing boom and collapse, and the resultant financial crisis were the consequence of inadequate financial stability policies, notably outdated regulation, lax supervision and policy interventions that distorted incentives in the housing and financial markets.

Our paper contributes to this debate by assessing the Bernanke hypothesis. In the first section we compare monetary and financial stability policies in Canada and the United States during the recent boom and examine whether differences in the policies of the two countries can account for the differences in their economic performance. We find evidence consistent with the Bernanke hypothesis. Although Canadian monetary policy was more conservative, likely because of its explicit inflation target, it is the difference in financial stability policies that largely explains the difference in the extent of the financial and economic expansion in the two countries. In the next section of the paper, we repeat this exercise for the 1920s. Again Canadian monetary policy is more conservative than U.S. monetary policy, largely because of different approaches to restore the prewar gold standard. This difference helps to explain relative economic performance during the booms, which were similar in both countries. The subsequent busts owe much to inadequate financial stability policies that failed to control the rapid increase in credit that fuelled the 
housing and stock market booms. Poor post-crisis monetary and exchange rate policies in both countries aggravated the subsequent economic slowdown.

Interestingly, the recent crisis demonstrates that while central banks seem to have learned the lessons from the Depression experience in terms of how to use monetary policy and liquidity provision to respond to a financial crisis, the lessons for financial stability policy were much less absorbed. Central banks, including the Fed and the BoC, responded immediately and boldly to the crisis with aggressive policy rate declines and large and pervasive increases in the provision of liquidity. Exchange rates were also allowed to depreciate to facilitate the adjustment. In contrast, many of the financial vulnerabilities that were realised in the 1920s, because of inadequate micro and macro prudential regulation and supervision were allowed to re-emerge in the run-up to the recent crisis: excess leverage, in part by pyramiding investment strategies; procylical margins and asset fire sales; mortgage securitization and perverse incentives; moral hazard and too-big-to fail; opaque instruments and asymmetric information; and the underassessment and under-pricing of risk by uninformed investors, including those from abroad.

\section{Recent Financial Crisis: Why Canada Fared Better than the United States}

Over the recent period in the 2000s, Canada experienced a smaller economic boom and a smaller bust when the global financial crisis hit than the United States. To see this, consider the U.S. and Canadian macroeconomic performance in 2000's; Figures 1 and 2 show the behaviour of output gap (expressed as percentage deviation between actual and potential output) and inflation (expressed as 4-quarter percentage change in core CPI index) in the two countries. Both countries experienced low inflation rates (between 1-3 \%) throughout the 2000's. There are important differences, however, in the behaviour of output in the two countries. The U.S. output 
gap was larger than the Canadian gap during the expansion from 2003 to 2006, with actual exceeding potential output, but fell much below the Canadian levels after the financial crisis in 2007.

To understand the source of these differences in output movements, we next consider monetary and financial stability policies in the two countries. Figure 3 examines the U.S. interest rate policy during the 2000's. It shows quarterly values of the federal funds rate, and to illustrate the Taylor argument, it compares these with values determined by a simple Taylor rule of the following type:

$$
R_{t}=\bar{r}+\pi^{*}+\alpha\left(\pi_{t}-\pi^{*}\right)+\beta \hat{y}_{t}
$$

where $R_{t}$ denotes the policy interest rate, $\bar{r}$ and $\pi^{*}$ represents the natural real rate and the target inflation rate, and $\pi_{t}$ and $\hat{y}_{t}$ are the (4-quarter) inflation rate and output gap. As originally proposed by Taylor (1993), we set $\bar{r}=\pi^{*}=2.0$ and $\alpha=\beta=0.5$ in calculating the ruledetermined policy rate in the figure. As noted by similar comparisons by others, the U.S. policy rate was set well below the hypothetical Taylor rule rate. Of course, such evidence is sensitive to specification of the Taylor rule and, in particular, to the indexes used to measure inflation and the output gap. Most notably, Bernanke (2010) argues that the gap between the rule and the actual rate is less if a real-time forecast of inflation is used instead of the actual rate because U.S. expected inflation was much lower than it turned out to be (Dokko et al., 2009). Bernanke (2010), however, does not provide an explanation of these fairly persistent forecast errors. We next examine how the Canadian monetary policy differed from the U.S. policy over this period. Figure 4 compares the behaviour of the policy rates for the two countries. The Canadian 
target rate generally follows the movements of the federal funds rate, but during the critical 2002-04 period of low U.S. interest rates, the Canadian rate remained significantly higher. Indeed the Canadian-U.S. interest rate differential increased during this period and rose to about 2\% in 2003Q2. The interest rate comparison also shows that Canadian interest rate did not increase as sharply as the U.S. rate during the 2004-06 period.

The Canadian interest rate policy rate has also been compared with the policy prescribed by a Taylor rule. In an annual review of the Canadian economy, the OECD (2010) argues that the Canadian policy rate was well below the Taylor rule rate during the pre-crisis period, and the loose monetary policy during this period was responsible for the housing boom in Canada. ${ }^{3}$ Indeed, estimating the coefficients of Taylor rule equation (1) for Canada using quarterly data for from 1990Q1 to 2001Q4, the Canadian target rate is shown to be significantly below the Taylor rule rate in the pre-crisis period from 2002 to 2007(see Figure 5). ${ }^{4}$ The standard rule, however, does not account for the fact that the Canadian policy rate may also be set in response to the U.S. policy rate in order to avoid large exchange rate movements. ${ }^{5}$ We thus also estimated a modified rule that also includes the U.S. policy rate. ${ }^{6}$ As also shown in Figure 5, the Canadian policy rate does not diverge much from the rate generated by the modified Taylor rule rate over the period 2000-2007. Canadian monetary policy in the 2000's thus does not appear to depart much from its behaviour in 1990's. In particular, the Canadian policy interest rate was correlated with U.S.

\footnotetext{
${ }^{3}$ A cross-country study of 20 countries by IMF (Fatas et al., 2009) also suggests that the Canadian interest rate was substantially below the Taylor rule rate.

${ }^{4}$ The Taylor rule rate is calculated based on coefficients obtained by estimating the following form of the rule by OLS: $R_{t}=c+\alpha \pi_{t}+\beta \hat{y}_{t}$, where $c=\bar{r}+(1-\alpha) \pi^{*}$.

${ }^{5}$ For example, Lubik and Schorfheide (2007) estimate a general equilibrium model to provide evidence that the Canadian interest rate rule includes the nominal exchange rate.

${ }^{6}$ The modified form of the estimated equation is: $R_{t}=c+\alpha \pi_{t}+\beta \hat{y}_{t}+\delta R_{t}^{u s}$, where $R_{t}^{u s}$ is the U.S. policy rate. The estimation period (1990Q1-2001Q4) is the same as in the OECD study and excludes the 1980's which represent the transition to lower inflation targets. Also, in the augmented Taylor rule, the output gap coefficient is not significantly different than zero, which result may indicate that Canada had an explicit inflation targeting framework, whereas the U.S. had a dual mandate.
} 
policy rate over both periods and the inclusion of the U.S. interest rate increases the explanatory power of the Taylor Rule equation. ${ }^{7}$ However, as discussed above, the Canadian interest rate movements were more moderate than U.S. movements during the 2002-2006 period.

A key mechanism for the transmission of monetary policy effects is the adjustment in the ex ante real interest rates. This channel is highlighted in the new-Keynesian DSGE models. ${ }^{8}$ It is, however, difficult to develop satisfactory measure of expected real rates as the process determining inflationary expectations is not well understood. Arguably, expected inflation rates depend on both forward-looking (model-consistent) and backward-looking components. We do not attempt to construct an index of the expected inflation rates, but for illustrative purposes, examine the behaviour of real policy rate defined simply as the nominal policy rate minus 4quarter core CPI inflation. Figure 6 compares the behaviour of the real policy rates in Canada and the United States. According to our simple measures, policy real rates in both countries fell sharply in 2001. The U.S. rate stayed below the Canadian rate till 2005 and was negative over most of the period.

As the financial crisis is typically identified with collapse of the U.S. housing boom, there has been considerable interest in assessing the contribution of U.S. monetary policy in generating the housing boom. For example, using a VAR model, Jarocinski and Smets (2008) find that low interest rates in the US had a significant effect on house prices and housing investment. Other

\footnotetext{
${ }^{7}$ This correlation may, however, be spurious if it reflects similar responses to common external shocks due to omitted variables and may not necessarily reflect the desire to lean against exchange rate movements.

${ }^{8}$ The basic versions (e.g., Clarida, Gali, and Gertler, 1999; Woodford, 2003) do not assign a prominent role for monetary aggregates. These models, however, do not incorporate financial frictions, and monetary aggregates or interest rate spreads could be an important part of the transmission mechanism in the presence of these frictions (Bernanke, Gertler and Gilchrist, 1999; Goodfriend and McCallum, 2007; Canzoneri et al., 2008) Also, changes in ex-post real interest rates would have distributional effects in non-representative agents versions
} 
studies (e.g., Dokko et al., 2009) suggest that monetary policy was not a major factor in causing the housing boom and subsequent collapse.

To assess this issue further, we compare the experience of Canada and the United States. Figure 7 shows the behaviour of house prices: 3 month moving average of S\&P Case-Shiller index for the United States and Teranet index for Canada. ${ }^{9}$ This figure shows that the rise in house prices was much steeper in the United States over the period 2000 to 2006. U.S. house prices increased by $100 \%$ over this period as opposed to $71 \%$ for Canadian prices. U.S. house prices started declining in 2007. Canadian house prices fell somewhat during the most intense period of the crisis in 2008-09, but then continued to increase while the U.S. house prices collapsed. It is likely that this stark difference in the behaviour of U.S. house prices relative to Canadian house prices does not solely reflect the potential differences in the stance of monetary policy. While one could argue that U.S. monetary policy was looser as measured by simple Taylor Rule gaps, it is unlikely that these differences alone can account for the significant deviation in the house price behaviour in the two countries.

The prolonged post-crisis collapse of the U.S. housing market versus the relative strength of the Canadian housing market is consistent with an explanation based on Canada-U.S. differences in financial regulation and supervision and overall government housing policy. In particular, Bernanke (2010) notes that the United States had an explicit policy over this period to promote homeownership, particularly among those families who had not previously had access to mortgage financing. This policy as well as those that deregulated banking to allow deposit-taking banks to participate in higher risk capital market activities and increase leverage, in part through

\footnotetext{
${ }^{9}$ These are comparable price series because they are both quality adjusted and data are drawn from major urban areas.
} 
off-balance sheet securitization vehicles exacerbated the risks. ${ }^{10}$ These policies and resultant rise in the issuance of subprime mortgages in the United States did not occur in Canada. Moreover, the extent of mortgage securitization was much less; thus the perverse "no skin in the game" or "originate and distribute model” was much less pervasive. As a consequence, the incentives to lower underwriting standards to issue mortgages to high-risk households and then securitize them was much less. In 2007, 15\% of the U.S. mortgages were subprime versus 3\% in Canada, and $60 \%$ of U.S. mortgages were securitized versus 30\% in Canada (Kiff 2009). Consequently, when the U.S. recession took hold in 2007-09, house prices collapsed by about 30\%, mortgage default rates shot up and the value of structured (often subprime) mortgage products declined sharply. Given how much of these toxic assets remained on the highly leveraged balance sheets of major U.S. banks, the U.S. banking system teetered on the edge of systemic insolvency and massive government bailouts were required to prevent a total collapse. ${ }^{11}$

While runs on deposit-taking banks did not occur, largely because of the presence of deposit insurance, and later in the crisis, blanket FDIC deposit guarantees, runs occurred in the lightly regulated shadow banking markets, including money market mutual funds and repurchase (repo) markets. ${ }^{12}$ Other core financial markets, including the interbank market and over-the-counter derivatives, seized. To fill the bank funding gap, the Federal Reserve and U.S. Treasury stepped in to guarantee money market mutual funds and inject massive amounts of liquidity into the U.S. financial system via a number of different programs. ${ }^{13}$ The situation in Canada was very

\footnotetext{
10 Angelides Commission Report (2011, pp. 64-66)

${ }^{11}$ A number of observers including Obstfeld and Rogoff (2011) have stressed the relationship between these financial imbalances in the United States and its current account deficits. Lorenzo Bin-Smaghi (2008) describes them as "two sides of the same coin" as capital flows "searching for yield" flooded into U.S. financial markets and exploited and exposed regulatory weaknesses (Bernanke 2010). Bertaut et al (2012) provide a more detailed assessment of the role of foreign investors in asset-backed securities.

${ }^{12}$ See Angelides (2011), Chapter 2.

${ }^{13}$ See Fleming (2012).
} 
different; house prices declined by about $9 \%$ in 2008-09, but then quickly recovered and continued to increase. Canadian banks did not experience significant losses or failures. Despite being universal banks, regulation and effective supervision prevented Canadian banks from becoming too dependent on short-term funding and unduly exposed to the higher risk capital market activities (Ratnovski and Huang, 2009). Mortgage under writing and securitization standards were also higher and generally enforced. ${ }^{14}$ Indeed, Table 3 shows that Canada went into the 2007-8 financial crisis with a financial regulatory and supervisory framework that had been significantly strengthened, especially with the creation of the Office of the Superintendent of Financial Institution. In contrast, Fed Chairman Bernanke in his testimony to the Angelides Commission said that "the Gramm-Leach-Bliley requirements made it difficult for any single regulator to reliably see the whole picture of the activities and risks of large, complex banking institutions" (Angelides, 2011, p. 55). All in all, the experience of the two countries provides support for the Bernanke Hypothesis. The difference in the behaviour of the housing prices in these countries over this period, in particular, the U.S. boom and collapse is more likely due to differences in mortgage market and banking regulation and supervision than to differences in monetary policy.

\section{Roaring Twenties and the Great Depression: The Canadian and U.S. Experiences}

The U.S. experience and the behaviour of the Federal Reserve in the economic boom and bust during the 1920's and early 1930's have been studied extensively. It is now generally agreed that, as argued by Friedman and Schwartz (1963), the failure of the Fed to prevent the large decline in

\footnotetext{
${ }^{14}$ Some government and central bank liquidity support was needed in Canada as global bank funding markets
} dried up. 
the money stock due to bank panics turned a recession into the Great Depression. ${ }^{15}$ It is also well recognized (e.g., Bernanke 2002, White, 1990a ) that tight monetary policy in 1928-29 caused an economic slowdown that lead to the stock market crash in October 1929 and the subsequent contraction. There is less agreement on whether easy monetary policy in 1924-25 contributed significantly to economic expansion and the stock market boom in the mid and late 1920 's. ${ }^{16}$ We explore this question further below.

There were significant differences between the periods prior to the economic booms of the 1920's and 2000's. While the latter period followed over a decade and a half of stable economic conditions under rule-based monetary policy, the former period represented a transitional state in which the Fed was in its early years and the appropriate rules of monetary policy were being developed and debated, and the gold standard as an international monetary system had not yet been restored. Federal Reserve Banks set the discount rates, but borrowing by member banks at these rates was discouraged and open market operations were also used as a tool of monetary policy. The Fed had enough instruments to control short term interest rates, and this power was also available even after the world-wide restoration of the gold standard because of its large holding of gold reserves and a significant margin between import and export gold points for Europe. $^{17}$

\footnotetext{
${ }^{15}$ Bernanke (1983) argues that monetary factors alone cannot explain the depth of the Great Depression in the United States. He maintains that the U.S. bank failures not only reduced the money supply, but also disrupted credit intermediation and this exacerbated the economic decline.

${ }^{16}$ Freidman and Schwartz (1963) and Meltzer (2003) view the conduct of U.S. monetary policy during the 1920s as generally appropriate because inflation was low and stable and output growth relatively robust. Hayek, Robbins and Robertson, however, felt that the Fed policy contributed to excess investment during the 1920s (see Laidler, 2003, and Wheelock, 1992, for summary of these criticisms of U.S. monetary policy). They argue that given the rapid technological growth over this period, deflation would have occurred in the absence of monetary expansion.

${ }^{17}$ The large stock of gold reserves enabled the Fed to influence money supply and the interest rates in the rest of the world. The gold-point margin arising from transportation costs implied some room for the home-foreign interest rate spread to vary. Indeed, in the presence of this margin, the gold standard could be viewed as a target zone exchange rate system. See Bordo and MacDonald (2005)for evidence on such characterization for the classical gold standard.
} 
Figure 8 shows monthly values of the New York Fed discount rate and the 3-month Treasury bill rate from January 1923 to December 1933, the period after the short boom and bust of 1921-22. The discount rate was decreased (in a number of steps) from 4.5\% in April 1924 to 3.0\% in September 1924 and kept at this level till February $1925 .{ }^{18}$ The rate was raised to 3.5\% in March 1925 and maintained at this value until December 1925. The 3-month Treasury bill rate also declined significantly during this period. The monetary policy in this period appears to be largely motivated by the downturn in 1924, but may also have been influenced by the desire to facilitate UK's return to the gold standard. ${ }^{19}$ Given the magnitude of the reduction in the interest rates and the duration over which they stayed at low levels, a case can be made that this easy money episode played an important part in the development of 1920's boom. Although the CPI inflation rate exhibited modest variability in the 1922-1929 period, the average inflation rate in this period was equal to zero. If inflationary expectations during this period were also close to zero, there was a sizable decline in the real interest rates in the 1924-25.

It is also interesting to examine whether the low interest rates in this period represent an excessive deviation from normal policy similar to the easy money policy of 2002-4. White (2009) has compared the U.S. policy interest rate (represented by the New York Fed discount rate) with the rate determined by simple Taylor rules (using coefficients suggested by Taylor, but changing the inflation target to zero and the real interest rate to 4\%) in the1920's. ${ }^{20}$ Movements

\footnotetext{
18 The discount rate was also decreased temporarily in the summer of 1927. This decrease was seen as part of a coordinated interest agreement among the Fed, Bank of England, Banque de France and the Reichsbank to reequilibrate the allocation of gold and stabilize the gold standard (Eichengreen and Michener, 2003). Eichengreen (1992, p.213) describes this agreement as "admirable instance of international cooperation."

${ }^{19}$ The discount rate reductions in the 1924-25 period were generally viewed (e.g., Meltzer, 2003) as appropriate counter-cyclical measures. The low U.S. interest rates lead to an outflow of gold especially to Britain (which set a higher discount rate), and thus also helped strengthened Bank of England's reserve position before U.K.'s return to gold standard (Eichengreen,1992, chapter 7).

${ }^{20} \mathrm{He}$ also estimates the coefficients of several versions of the Taylor rule equations for the 1922-29 period, and finds that the response coefficients were reasonable.
} 
in the actual rate tend to be smaller than the Taylor rule rate, and the actual rate was below the rule-based rate by about 2\% during the 1925-6 period, which was critical for the housing boom that occurred over this period. However, White estimates that a counterfactual policy of raising the interest rate to the levels specified by the rule would not have made a major difference to the housing boom. White attributes the housing boom to excess mortgage credit expansion fuelled by inadequate financial stability policies, namely the securitization of mortgages combined with a reduction in lending standards and lax supervision. ${ }^{21}$

We next review Canadian monetary policy in this period and examine how it differed from the U.S. policy and whether these differences had any influence on the macroeconomic performance of the two countries. During the 1920's, Canada operated without a central bank, but the Canadian Ministry of Finance did provide access to a lending window. According to the Finance Act of 1914, the banks could borrow from the Ministry at an interest rate called the "advance rate" against a collateralized line of credit. The lines of credit were generally not a constraint as actual borrowing tended to be a small proportion of the credit limit (Shearer and Clark, 1984). The 1914 Finance Act set a floor of 5\% for the advance rate (with a provisions for a lower rate for special advances), but this floor was removed in 1923 by a new Finance Act. After the removal of the floor, the advance rate became the primary instrument of monetary policy in Canada, although it was changed infrequently.

Canada was on the gold standard for only a short period from July 1926 to January 1929. Low costs of transporting gold between New York and Montreal implied a narrow interval between gold export and import points. During the gold standard period, the Finance Ministry thus had

\footnotetext{
${ }^{21}$ Canada also experienced a housing boom in the 1920s, which peaked in 1929. It was largely in housing construction rather than house prices (Firestone, 1951).
} 
limited room to vary the discount rate relative to the short-term rates in the United States. ${ }^{22}$ In pre- and post-gold standard periods, however, Canada had the power to follow an independent interest rate policy. The Canadian authorities, however, appear to have been reluctant to allow the exchange rate to deviate much from parity and tended to respond to short-term U.S. interest rates. The Canadian interest rate policy did deviate significantly from the U.S. policy during certain periods. Figure 9 compares the behaviour of the advance rate to the New York Fed discount rate from January 1923 to December $1933 .{ }^{23}$ The advance rate was not decreased as much in the 1924-25 episode of easy U.S. monetary policy and was not increased as much in the later 1928-29 episode of tight U.S. monetary policy. There were also important monetary policy differences during the Great Depression period.

To explore the impact of these monetary policy differences on economic activity in Canada relative to the United States, we construct a measure of output gap for the two countries. As estimates of quarterly GDP are not available for this period, especially for Canada, we base our measure on industrial production. ${ }^{24}$ As an estimate of normal or potential output, we fit a linear trend to quarterly industrial production data from 1919 Q1 to 1939 Q4 for both countries. Figure 10 compares the deviation of industrial production from this trend (for the 1923-1933 period) as a rough indicator of the output gap in the two countries. As the figure shows, the industrial production gap in Canada was lower than the U.S. gap during the 1924-5 episode, and was

\footnotetext{
22 There may also have been significant departures from interest parity because the financial markets in Canada were not well developed at that time and interest rate arbitrage between Canada and the US may have involved substantial transaction costs.

${ }^{23}$ The figure shows the ordinary advance rate applicable to any eligible collateral. There was also a lower special rate applicable to loans secured by special issues of government securities, but after 1923, this rate was only available for selected periods, from October 1928 to October 1931 and after October 1932 (Shearer and Clark, 1984).

${ }^{24}$ An alternative measure could be based on unemployment rates. Although official unemployment data for Canada are not available before 1945, Gower (1992) has estimated Canadian unemployment since1921. It is difficult to determine how comparable Canadian unemployment estimates are with the US estimates. Gower's estimates do suggest, however, that Canada suffered lower unemployment than United States during the Great Depression (the Canadian and U.S. unemployment rates peaked at $19.1 \%$ and $25.2 \%$ respectively).
} 
higher during the 1928-29 episode. Further evidence on the impact of the monetary policy differences is provided in Figure 11, which shows the behaviour of 4-quarter CPI inflation in the two countries. The Canadian inflation rate was lower than the U.S. rate during the first and higher during the second episode. Monetary policy differences between Canada and the Unites States over this period are thus reflected in output and inflation outcomes in the two countries.

To examine the role of credit growth and financial leverage in exacerbating the economic boom in the 1920s, we consider the contribution of credit growth to asset prices, primarily stock and house prices, in Canada and the United States in the 1920s. Eichengreen and Michener (2003) argue that in the United States "credit fuelled a real estate boom in 1925, a Wall Street boom in 1928-9 and a consumer durable spending spree spanning the second half of the 1920s”. While White (2009) points to securitization and lax lending standards for increases in housing credit, ${ }^{25}$ Galbraith (1955) and Eichengreen and Michener identify unregulated investment trusts and margin borrowing as well as innovations in consumer credit for durables purchases as important new sources of credit growth and leverage over the period. Higher leverage was achieved by purchasing stocks on margin for as low as $10 \%$ and by "pyramiding" investment trusts (Galbraith, 1955). ${ }^{26}{ }^{27}$ Table 1 compares the exponential increases in investment trusts in Canada and the United States over this period. The expansion was significantly greater in the United States given the much greater overall size of the stock market.

\footnotetext{
${ }^{25}$ Rajan and Ramcharam (2012) examine the boom and bust in land prices in the United States in the 1920s. They find that credit availability fuelled the land price boom and the resulting bust lead to increases in bank failures for those banks that were overleveraged and overexposed to land loans.

${ }^{26}$ Such pyramiding is analogous to the $\mathrm{CDO}^{2}$ and $\mathrm{CDO}^{3}$ etc. instruments in 2000s, where CDO refers to collateralized debt obligation.

${ }^{27}$ Kindleberger (1978) and Minsky (1986) also stress the pervasive information problems that contributed to the stock market excesses. Such information problems are analogous to those that occurred in the recent crisis; for example, huge counterparty exposures were largely unknown especially in the OTC derivatives and repo markets.
} 
In the United States, bank loans increased by 35\% from 1923-29, while in Canada, bank loans, accelerated over the latter half of 1920s, rising by 60\% over the years from 1923-29. Domestic bank loans however only explain part of the story as there were other forces affecting domestic credit conditions. For example, in the United States there were substantial borrowings from abroad, especially in the latter part of 1929, much of which were intermediated through the New York call loan market. Call loan rates in the New York call money market increased steadily to $12 \%$ and this drew in funds from non-financial U.S. corporations (White, 1990b) and also from the rest of the world. ${ }^{28}$ Because of the pressure exerted by these gold outflows on its exchange rate, Canada suspended gold convertibility in 1929.

In an effort to capture these different factors, Eichengreen and Michener (2003) construct a credit conditions index, based on Borio and Lowe (2002), for a set of advanced economies that combines deviations from trends of the ratios of M2, stock prices and investment to GDP. They find a sharp spike in credit conditions in Canada and the United States in 1928. They also find evidence that the size of this index, especially in interaction with the stock price index, helps predict the depth of the subsequent economic downturn.

To explore further the impact of this credit expansion on asset prices, consider stock market prices in the two countries (see Figure 12). U.S. stock prices rose at a slightly faster pace than Canadian prices until 1925, at somewhat slower pace until 1928, and then they rose sharply and reached a higher peak than Canadian prices in 1929. The difference in stock market price behaviour in 1929 does not appear to reflect monetary policy differences, but is more likely related to the more rapid expansion in U.S. credit.

\footnotetext{
${ }^{28}$ In this instance, when gold flows are driven by expected capital gains from rapid asset price increases, the gold standard has a pro-cyclical impact.
} 
Because both countries lacked effective financial stability policies, in the form of micro and macroprudential tools, they resorted to raising policy interest rates in the latter part of this period in attempt to stem the rise in asset prices, and in Canada's case, to help maintain its peg to gold. The resulting stock market crash and severe economic downturn are testament to the bluntness of monetary policy as tool for maintaining financial stability and need for better regulation and supervision to prevent the occurrence of such rapid asset price increases. ${ }^{29}$ To address these shortcomings in financial regulation and supervision, substantial changes were made to laws governing the financial system. In the United States, this includes passing the Glass-Steagall Act and the Securities Exchange Act. (See Table 2)

Figures 10 and 11 also show that the decline of output and inflation in Canada during the Great Depression was nearly as severe as in the United States. ${ }^{30}$ The transmission of the Great Depression from the United States to the rest of the world has been linked to the gold standard. The United Kingdom and the Scandinavian countries left the gold standard in 1931 and fared better than the United States while France and Germany stayed on the standard beyond 1933 and fared worse (Choudhri and Kochin, 1980; Bernanke, 1995). Canada was, in fact, the first country

\footnotetext{
${ }^{29}$ Galbraith (1955), White (1990b) and Meltzer (2003) examine the Fed's reluctance to raise interest rates sufficiently to restrain the rapid expansion in credit and stock prices. Meltzer explains this behavior as follows: inflation was low, growth was not excessive and there were concerns about the international impact. The Fed recognized the speculative use of credit but was "reluctant to use a general instrument to deal with what it regarded as special circumstances” (p. 236). White (1990b) argues that while the New York Fed wanted to raise rates to rein in bank lending to brokers, the Board preferred "direct pressure" on bank members (p. 74). Galbraith writes "Federal Reserve authorities are held to be not so much unaware or unwilling as impotent. They would have liked to stop the boom, but they lacked the means" (p.34).

${ }^{30}$ Although Canada had a debt crisis like the United States, it did not have a banking crisis because of Canada's branch banking system (Bernanke, 1983).Nonetheless, Canada still experienced similar and severe economic contraction (Amaral and MacGee, 2002). Bordo (1986), Drummond (1991), Kryzanowski and Roberts (1993) argue that Canadian government policy also played an important role in preventing bank failures. In particular, Kryzanowski and Roberts maintain failures were prevented by an implicit guarantee on bank deposits and regulatory forbearance. Drummond notes that Canadian banks were also shielded from losses by government guarantees on advances to wheat pools and by government-led support for securities' prices. Canadian banks were also not allowed to issue mortgages and their exposure to the stock market was less. Safarian (1959) stresses the degree of openness of the Canadian economy, which was four times more dependent on exports than the U.S. economy, as the explanation of why the Canadian depression was almost as severe despite the lack of bank failures.
} 
to abandon the gold standard, but did not derive any benefits from this policy. There are two possible explanation of this puzzling behaviour. One explanation (Betts, Bordo and Redish, 1996) emphasizes the role of common real shocks that produced a contraction in both countries independent of the exchange rate regime. An alternative explanation, based on the presence of nominal rigidities and consistent with the evidence for other countries, argues that Canadian exchange rate regime did not permit sufficient exchange rate flexibility when Canada was off the gold standard. ${ }^{31}$

Figure 13 displays the monthly exchange rate (U.S. dollar per Canadian dollar) series. Except for a slight discount during January 1923 to August 1924, and October-November 1929, the exchange rate remained very close to parity until September 1931 when U.K. pound began depreciating. The Canadian dollar depreciated by about 17\% until December 1931 before recovering and fluctuating between $10 \%$ and $16 \%$ of parity till March 1933 when the U.S. also left the gold standard. The depreciation of U.K. pound was much larger during the same period. $^{32}$ The smaller Canadian dollar depreciation can be attributed to Canadian interest policy. The advance rate was maintained at a high level of $4.5 \%$ till 1931 while the US discount rate declined to $1.5 \%{ }^{33}$ This policy also raised the Canadian real interest rate relative to the US rate at a time when large deflation was bringing about a huge increase in real interest rates. Although there is controversy about how to measure the real rates in this period, our simple measure (nominal rate minus 4-quarter inflation ) indicates that the Canadian real policy rate stayed above the US rate from 1930Q3 to 1931Q4 and this differential rose to 4\% in 1931Q3 (see Figure 14) .

\footnotetext{
${ }^{31}$ See, for example, Bordo and Redish (1990), who claim that exchange rate did not change till September 1931 as a result of credible policy commitment to parity.

${ }^{32}$ The U.K. pound depreciated by about 31\% by December 1931, and then fluctuated between $24 \%$ and 33\% of its initial value.

${ }^{33}$ Some relief was provided by a lower special advance rate from September 1928 to October 1931, but this relief was not available from October 1931 to October 1932. Moreover, since the special rate was available only for limited advances, it is not clear if it was effective in lowering money market rates.
} 
The behaviour of the real interest may have offset the effect of the modest depreciation and could provide an explanation of Canadian poor performance during the Great Depression.

\section{Concluding Remarks}

There are interesting parallels between monetary policies in the booms of 1920's and 2000's for both United States and Canada. In both periods, the US monetary policy was unusually easy before the boom and became very tight at the end of the boom. Canadian monetary policy followed a similar course, but it was more moderate in the easy as well as the tight phase. The similar behaviour of Canadian monetary policy in the twin booms is remarkable because Canada did not even have a central bank in the early period. The monetary policy differences between the two countries affected their relative macroeconomic performance during the boom in each period: the Canadian output gap was smaller than the US gap in the early and larger in the late phase of the boom. However, these monetary policy differences between Canada and the United States in different stages of the booms do not explain their experience in the crashes that followed the booms.

In the recent financial crisis, Canadian economic activity did not decline as much as in the United States. Surprisingly, house prices in Canada kept on rising, after a temporary decline, while they fell sharply in the United States. Although a more moderate stance of Canadian monetary policy may have also helped, a likely explanation of why Canada fared better in the crises is that different financial stability policies prevented a decline in Canadian house prices.

Canada did not fare better than the United States during the Great Depression. Some spillover of the U.S. depression into Canada was inevitable because of Canada's proximity and economic ties with the United States. Interestingly, however, two factors could have helped Canada escape the 
severity of the depression. First, branch banking system in Canada made Canada less prone to banking crises. Second, and more important, Canada left the gold standard before the depression started and thus could have followed an independent monetary policy. However, Canada did not utilize these advantages by following an inflexible interest rate and exchange rate policy.

Interestingly, the key policy lessons from the Great Depression seemed to have been learned by central banks and other public authorities in the advanced economies because in the immediate aftermath of the recent financial crisis they responded quickly with sharp declines in policy rates, massive injections of liquidity and substantial exchange rate depreciations in some cases, such as Canada. In contrast, the monetary policy and financial stability policy lessons from the boom of the 1920s were not fully absorbed during the most recent boom. Some of the regulation that was put in place in the 1930s in response to the crisis of the 1920s (most notably the Glass-Steagall Act) was removed. Micro and macroprudential regulatory policies were not used effectively to counter the credit expansion and monetary policy generally leaned with the expansion rather than against it. Indeed, the U.S. banking system almost collapsed because of its close ties to the unregulated shadow banking and over-the-counter derivatives markets.

Fortunately, these lessons are now being taken into account, given the efforts of the G20 and Financial Stability Board, as well as central banks and other regulatory bodies, to put in pacing sweeping financial regulatory and supervisory reform and macroprudential policy to address systemic risks in the financial system, especially related to procyclicality. Basel III and DoddFrank are important examples. Central banks are also paying greater attention to financial stability and the nexus between financial stability and monetary policies. 


\section{References}

Amaral, P. and J. MacGee. 2002. The Great Depression in Canada and the United States: A neoclassical perspective. Review of Economic Dynamics, 5: 45-72.

Angelides Commission. 2011. Final Report of the National Commission on the Causes of the Financial and Economic Crisis in the United States. Washington: U.S. Government Printing Office.

Bernanke, B. 1983. Nonmonetary effects of the financial crisis in the propagation of the Great Depression. American Economic Review, 73: 257-276.

Bernanke, B. 1995. The macroeconomics of the Great Depression: A comparative approach. Journal of Money, Credit and Banking, 27:1-28.

Bernanke, B. 2002. Asset-price "bubbles" and monetary policy. Remarks before the New York Chapter of the National Association for Business Economics, New York, NY, October 15.

Bernanke, B. 2010. Causes of the recent financial and economic crisis. Statement before the Financial Crisis Inquiry Commission, September 2.

Bernanke, B. 2010. Monetary policy and the housing bubble. Presentation at the American Economic Association Annual meeting, January 3.

Bernanke, B., M. Gertler, and S. Gilchrist. 1999. The financial accelerator in a quantitative business cycle framework,” in J.B. Taylor and M. Woodford (eds.) Handbook of Macroeconomic. Vol. I C: 1341-93. Amsterdam: Elsevier Science, North-Holland.

Bertaut, C., L. Pounder DeMarco, S. Kamin and R. Tryon. 2012. ABS inflows to the United States and the global financial crisis. Journal of International Economics 88: 219-234.

Betts, C., M. Bordo, and A. Redish. 1996. A small open economy in depression: Lessons from Canada in the 1930s. Canadian Journal of Economics 39: 1-36.

Bini Smaghi, L. 2008. The financial crisis and global imbalances - two sides of the same coin. Speech at the Asia Europe Economic Forum conference "The Global Financial Crisis: Policy choices in Asia and Europe”, Beijing, 9 December. (available at http://www.bis.org/review/r081212d.pdf

Bordo, M. and R. MacDonald. 2005. Interest rate interactions in the classical gold standard, 1880-1914: was there any monetary independence? Journal of Monetary Economics 52: 307-327. 
Bordo, M. and A. Redish. 1990. Credible commitment and exchange rate stability: Canada’s interwar experience. Canadian Journal of Economics 23: 357-380.

Borio, C. and P. Lowe. 2002. Asset prices, financial and monetary stability - exploring the nexus. BIS Working Paper No. 114.

Canzoneri, M., R. Cumby, B. Diba, and D. Lopez-Salido. 2008. Monetary aggregates and liquidity in a Neo-Wicksellian framework. Journal of Money, Credit and Banking, 40: 16671698.

Choudhri, E. and L. Kochin. 1980. The exchange rate and the transmission of monetary disturbances. Journal of Money Banking and Credit 12: 565-574.

Clarida, R., J. Gali, and M. Gertler. 1999. The science of monetary policy: A New Keynesian perspective. Journal of Economic Literature 37: 1661-1707.

Dokko, J., B. Doyle, M. Kiley, J. Kim, S. Sherlund, J. Sim, and S. Van den Heuvel. 2009. Monetary policy and the housing bubble. Finance and Economics Discussion Paper No. 2009-49. Washington: Board of Governors of the Federal System. December.

Drummond, D. 1991. Why Canadian banks did not collapse in the 1930s. In H. James, H. Lindgren and A. Teichova (eds.) The Role of Banks in the Interwar Economy. Cambridge: Cambridge University Press.

Eichengreen, B. 1992. Golden Fetters: The Gold Standard and the Great Depression, 19191939. Oxford: Oxford University Press.

Eichengreen, B. and K. Michener. 2003. The Great Depression as a Credit Boom Gone Wrong” BIS Working Paper No. 137. September.

Estey Commission. 1986. The Report of the Inquiry into the Collapse of the CCB and Northland Bank. Ottawa: Supply and Services Canada.

Fatás, A. P. Kannan, P. Rabanal, and A. Scott. 2009. Lessons for monetary policy from Asset Price Fluctuations,” in World Economic Outlook (Fall), chapter 3. Washington: IMF.

Financial Stability Board. 2012. Peer Review Report of Canada. (published online at www.financialstabilityboard.org.)

Firestone, O.J. 1951. Residential Real Estate in Canada. Toronto: University of Toronto Press.

Fleming, M. 2012. Federal Reserve liquidity provision during the financial crisis of 2007-2009. Federal Reserve Bank of New York Staff Report No. 563.

Friedman, M., and A. Schwartz. 1963. A Monetary History of the United States, 1867 to 1960. Princeton: Princeton University Press. 
Galbraith, J.K. 1955. The Great Crash 1929. Boston: Houghton Mifflin.

Goodfriend, M. and B. McCallum. 2007. Banking and interest rates in monetary policy analysis: A quantitative exploration. Journal of Monetary Economics 54: 1480-1507.

Gower, D. 1992. A note on Canadian unemployment since 1921. Statistics Canada: Perspectives on Labour and Income 4: 8-30.

Kiff, J. 2009. Canadian residential mortgage markets: Boring but effective? IMF Working Paper No. 09/130.

Kindleberger, C. 1978. Manias, Panics and Crashes. New York: Basic Books.

Kryzanowski, L. and G. Roberts. 1993. Canadian banking solvency, 1922-40. Journal of Money, Credit and Banking 25(3): 361-376.

Laidler, D. 2003. The price level, relative prices and economic stability: Aspects of the interwar debate.” BIS Working Paper No 136, September.

Lubik, T. and F. Schorfheide. 2007. "Do central banks respond to exchange rate movements? A structural investigation. Journal of Monetary Economics 54: 1069-1087.

Macmillan Commission. 1933. The Report of the Royal Commission on Banking and Currency in Canada. Ottawa: J.F. Patenaude.

Meltzer, A. 2003. A History of the Federal Reserve: Volume 1: 1913-51. Chicago: University of Chicago Press.

Minsky, H. 1986. Stabilizing an Unstable Economy. New Have: Yale University Press.

Obstfeld, M. and K. Rogoff. 2009. Global imbalances and the financial crisis: Products of common causes. In Asia and the Global Financial Crisis: 131-72. Proceedings of a conference held by the Federal Reserve Bank of San Francisco, 19-20 October.

OECD. 2010. Annual Review of the Canadian Economy, September.

Partnoy, F. 2003. Infectious Greed. New York: Times Books.

Pecora, F. 1939. Wall Street Under Oath: The Story of Our Modern Money Changers. New York: A.M. Kelley.

Rajan, R. 2010. Fault Lines. Princeton: Princeton University Press.

Rajan, R. and R. Ramcharan. 2012. The anatomy of a credit crisis: The boom and busts in farm land prices in the United States in the 1920s. NBER Working Paper No. 18027. 
Ratnovski, L. and R. Huang. 2009. Why are Canadian banks more resilient? IMF Working Paper No. 09/152.

Safarian, E. 1959. The Canadian Economy in the Great Depression. Toronto: University of Toronto Press.

Shearer, R. and C. Clark. 1984. Canada and the interwar gold standard, 1920-35: Monetary policy without a central bank. In M. Bordo and A. Schwartz (eds.) A Retrospective on the Classical Gold Standard, 1821-1931. Chicago: University of Chicago Press.

Taylor, J. 1993. Discretion versus policy rules in practice. Carnegie-Rochester Conference Series on Public Policy 39: 195-214.

Taylor, J. 2008. The financial crisis and the policy responses: An empirical analysis of what went wrong. In A Festschrift in Honour of David Dodge's Contributions to Canadian Public Policy. Ottawa: Bank of Canada.

Taylor, J. 2012. "Monetary Policy Rules Work and Discretion Doesn't: A Tale of Two Eras," Journal of Money Banking and Credit, 44: 1017-1034.

Wheelock, D. 1992. Monetary policy in the Great Depression: What the Fed did and why. The Federal Reserve Bank of St. Louis Review, 74: 3-28.

White, E. 1990a. When the ticker ran late: The stock market boom and crash of 1929. In E. White (ed.) Crashes and Panics: The Lessons from History. Homewood, Ill.: Dow-Jones Irwin.

White, E. 1990b. The stock market boom and crash of 1929 revisited. Journal of Economic Perspectives 4: 67-83.

White, E. 2009. Lessons from the Great American real estate boom and bust of the 1920s. NBER Working Paper No. 15573.

Woodford, M. 2003. Interest and Prices: Foundations of a Theory of Monetary Policy, Princeton: Princeton University Press. 
Table 1. Formation of Investment Companies Prior to 1930

\begin{tabular}{|l|c|c|}
\hline $\begin{array}{l}\text { Year of } \\
\text { Formation }\end{array}$ & $\begin{array}{l}\text { Number of } \\
\text { American } \\
\text { Companies Formed }\end{array}$ & $\begin{array}{l}\text { Number of } \\
\text { Canadian } \\
\text { Companies } \\
\text { Formed }\end{array}$ \\
\hline 1924 and before & 37 & 2 \\
\hline 1925 & 26 & 1 \\
\hline 1926 & 24 & 3 \\
\hline 1927 & 89 & 14 \\
\hline 1928 & 130 & 9 \\
\hline 1929 & 203 & 21 \\
\hline $\begin{array}{l}\text { Total as of } \\
31 \text { December } 1929\end{array}$ & 509 & 50 \\
\hline
\end{tabular}


Table 2. Major Financial Reforms in Canada and the United States: Post 1929-32 Crisis

\begin{tabular}{|c|c|}
\hline Canada & United States \\
\hline $\begin{array}{l}\text { 1933: Ontario Securities Commission founded } \\
\text { - To enforce the } 1928 \text { Securities Fraud } \\
\text { Prevention Act, which included anti-fraud } \\
\text { provisions as well as provisions for the } \\
\text { regulation of brokers and salesman } \\
\text { 1934: Revision to the Bank Act } \\
\text { - } \text { Phased prohibition of note issue by banks } \\
\text { - Removal of super-liability of shareholders } \\
\text { Prohibition of the publication of bank } \\
\text { names on corporate prospectuses } \\
\text { 1934: Bank of Canada Act } \\
\text { Establishment of a central bank with the } \\
\text { sole right of note issue and to provide } \\
\text { loans/advances to commercial banks and to } \\
\text { serve as the government's fiscal agent } \\
\text { 1935: Dominion Companies Act } \\
\text { Required prospectuses with more } \\
\text { disclosure be supplied by underwriters for } \\
\text { all federally incorporated corporations and } \\
\text { strengthened provisions for disclosure in } \\
\text { the annual report and directors' } \\
\text { transactions in company's securities }\end{array}$ & $\begin{array}{l}\text { 1933: Banking (Glass-Steagall) Act } \\
\text { - } \quad \text { Required the separation of commercial and } \\
\text { investment banking activities into distinct } \\
\text { corporate entities } \\
\text { - Established the Federal Deposit Insurance } \\
\text { Corporation } \\
\text { - Allowed the Federal Reserve to discount } \\
\text { any “sound” asset, not just commercial } \\
\text { loans (1935 version of the Banking Act) } \\
\text { 1933: Securities Act } \\
\text { - Regulated the offer and sale of securities } \\
\text { across state lines; in particular, it required } \\
\text { issuers to fully disclose all material } \\
\text { information for potential investors via a } \\
\text { prospectus. } \\
\text { 1934: Securities Exchange Act } \\
\text { Established the Securities and Exchange } \\
\text { Commission, which was responsible for } \\
\text { enforcing the requirement of the Securities } \\
\text { Act, including that all new issues had to be } \\
\text { registered with the SEC and regulating } \\
\text { broker-dealers. }\end{array}$ \\
\hline
\end{tabular}

\footnotetext{
${ }^{34}$ Securities regulation falls within provincial jurisdiction. All of the provinces have securities commissions with similar powers. A passport system allows corporations to issue securities in various provinces.

${ }^{35}$ In 1935 the Finance Act of 1914 and the Dominion Notes Act of 1868 were repealed.
} 
Table 3. Major Financial Reforms in Canada and the United States: Pre-2007-8 Crisis ${ }^{36}$

\begin{tabular}{|c|c|}
\hline Canada & United States \\
\hline 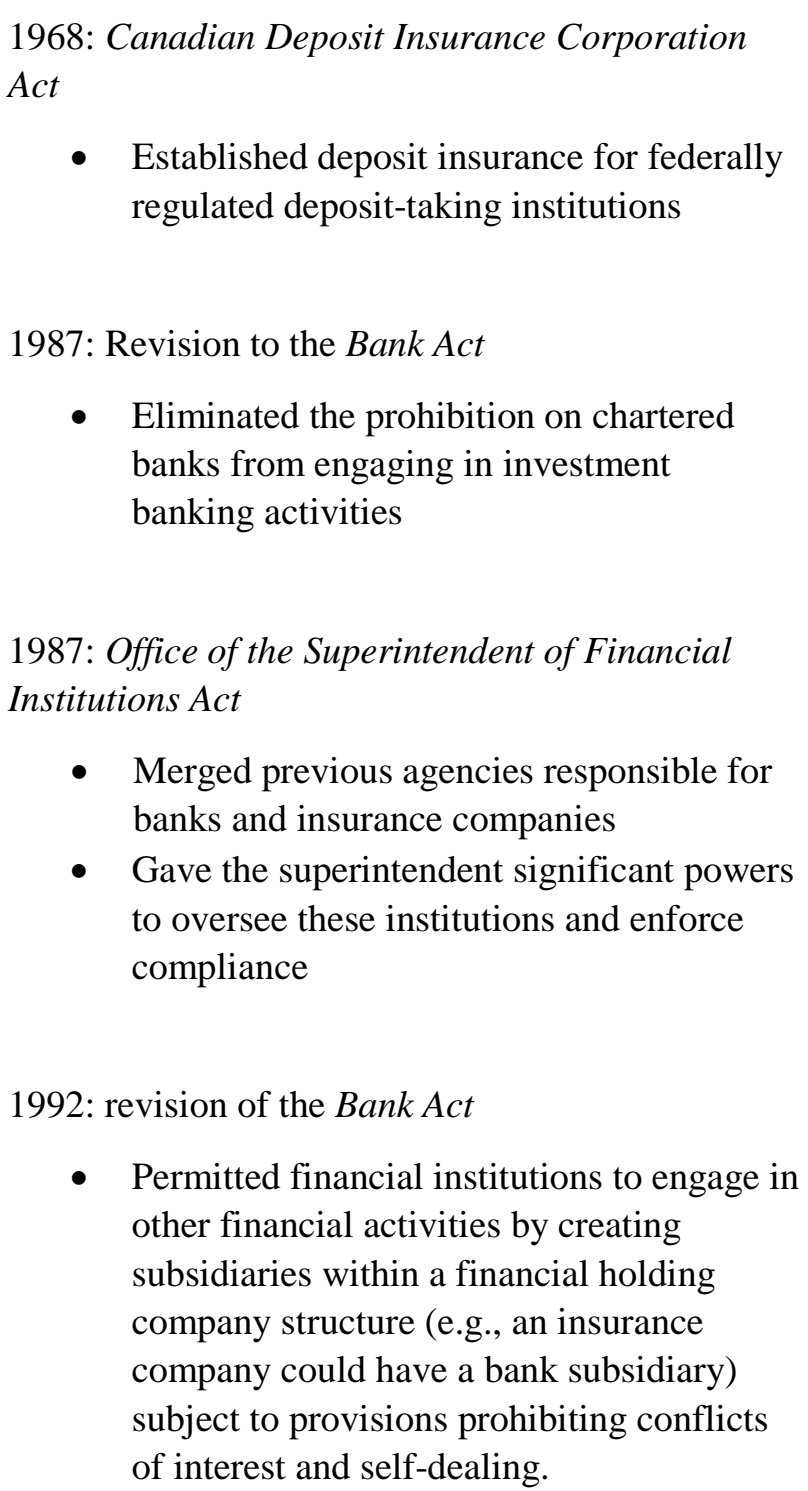 & $\begin{array}{l}\text { 1980: Depository Institutions Deregulation and } \\
\text { Monetary Control Act } \\
\text { - } \quad \text { Deregulated the lending and borrowing of } \\
\text { thrift institutions, including promoting the } \\
\text { issuance of mortgages that could be } \\
\text { securitized by the federal housing agencies. } \\
\text { 1992: Federal Housing Enterprise Safety and } \\
\text { Soundness Act } \\
\text { - Promoted home ownership by low income } \\
\text { and minority groups through increased } \\
\text { securitization by the housing agencies }{ }^{37} \\
\text { - } \\
\text { 1999: Gramm-Leach-Bliley Act } \\
\text { Allowed investment banks to own thrifts, } \\
\text { which gave them access to FDIC-insured } \\
\text { deposits without supervision of the Fed }\end{array}$ \\
\hline
\end{tabular}

\footnotetext{
${ }^{36}$ During this period the U.S. Federal authorities did not act to regulate the immense over-the-counter derivatives (swaps) market despite mounting concerns (Partnoy, 2003).

37 This act reinforced the 1977 Community Reinvestment Act, which required banks to lend to their local markets, especially in lower-income, predominantly minority areas (Rajan, 2010).
} 
Figure 1. Output Gap in Canada and the United States

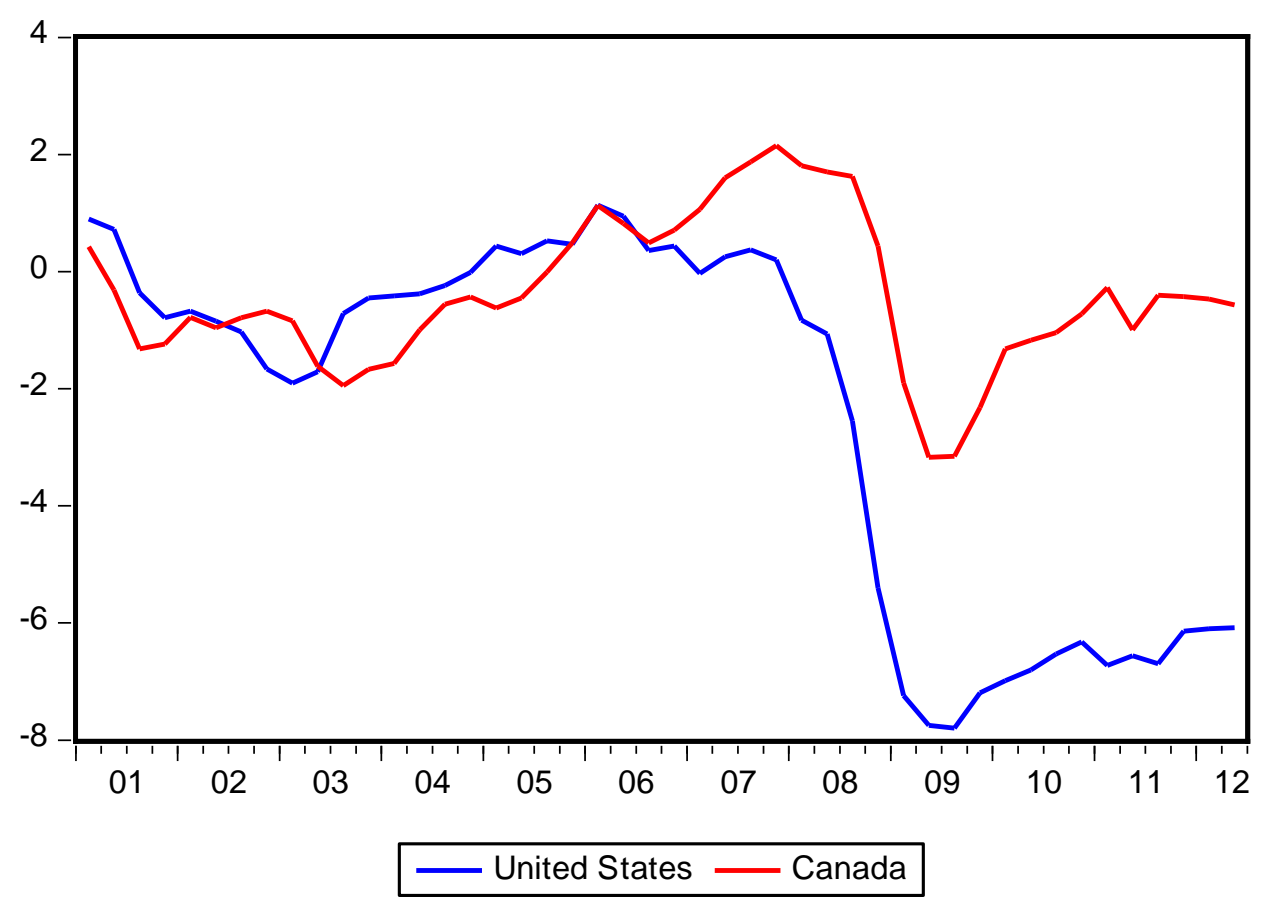

Source: See Appendix 1.

Figure 2. Core CPI inflation in Canada and the United States

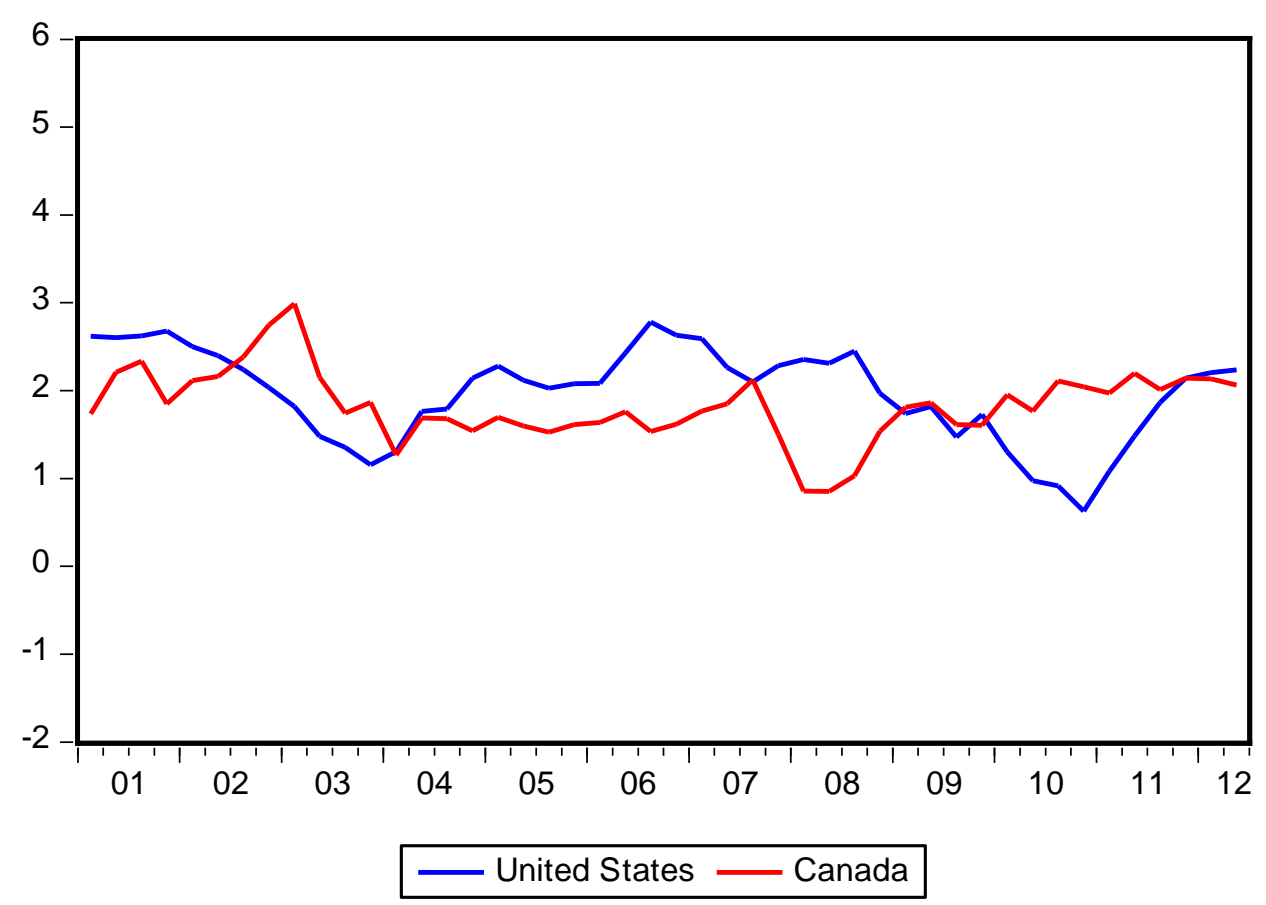

Source: See Appendix 1. 
Figure 3. US Federal Funds Rate Compared with a Simple Taylor Rule Rate

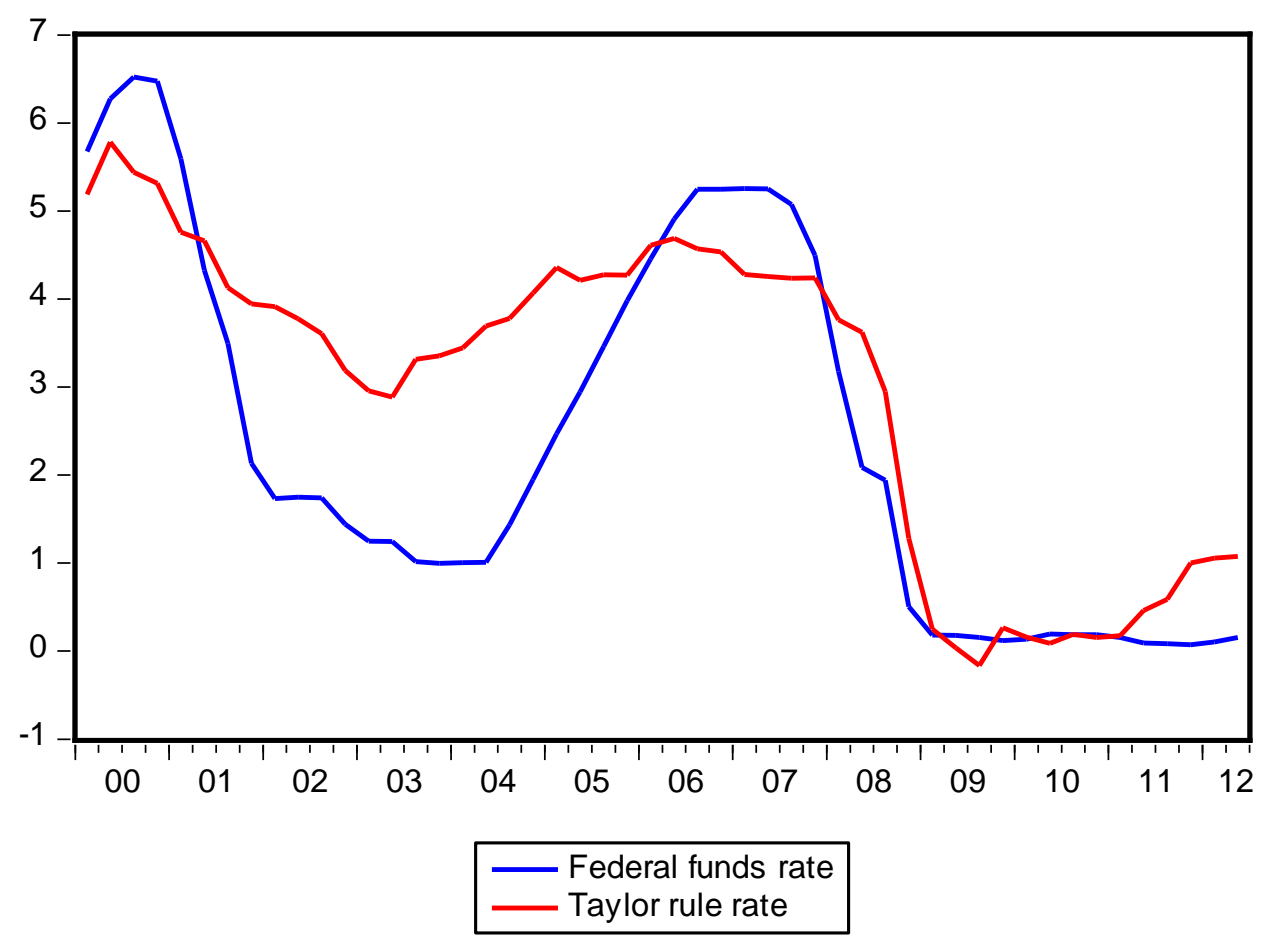

Source: See Appendix 1.

Figure 4. U.S. Federal Funds Rate Compared with Canadian Target Rate

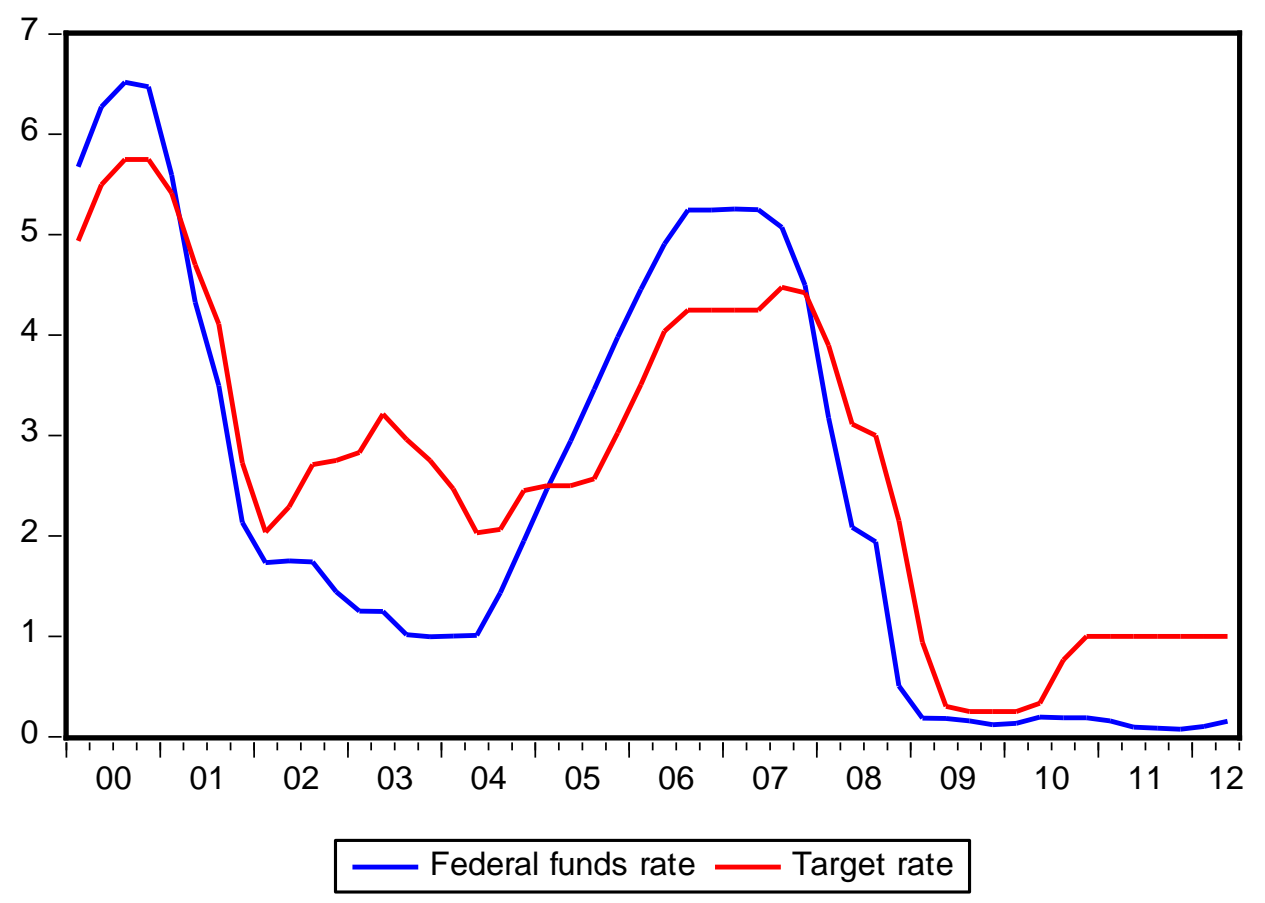

Source: See Appendix 1. 
Figure 5. Canadian Target Rate Compared with Taylor Rule Rates

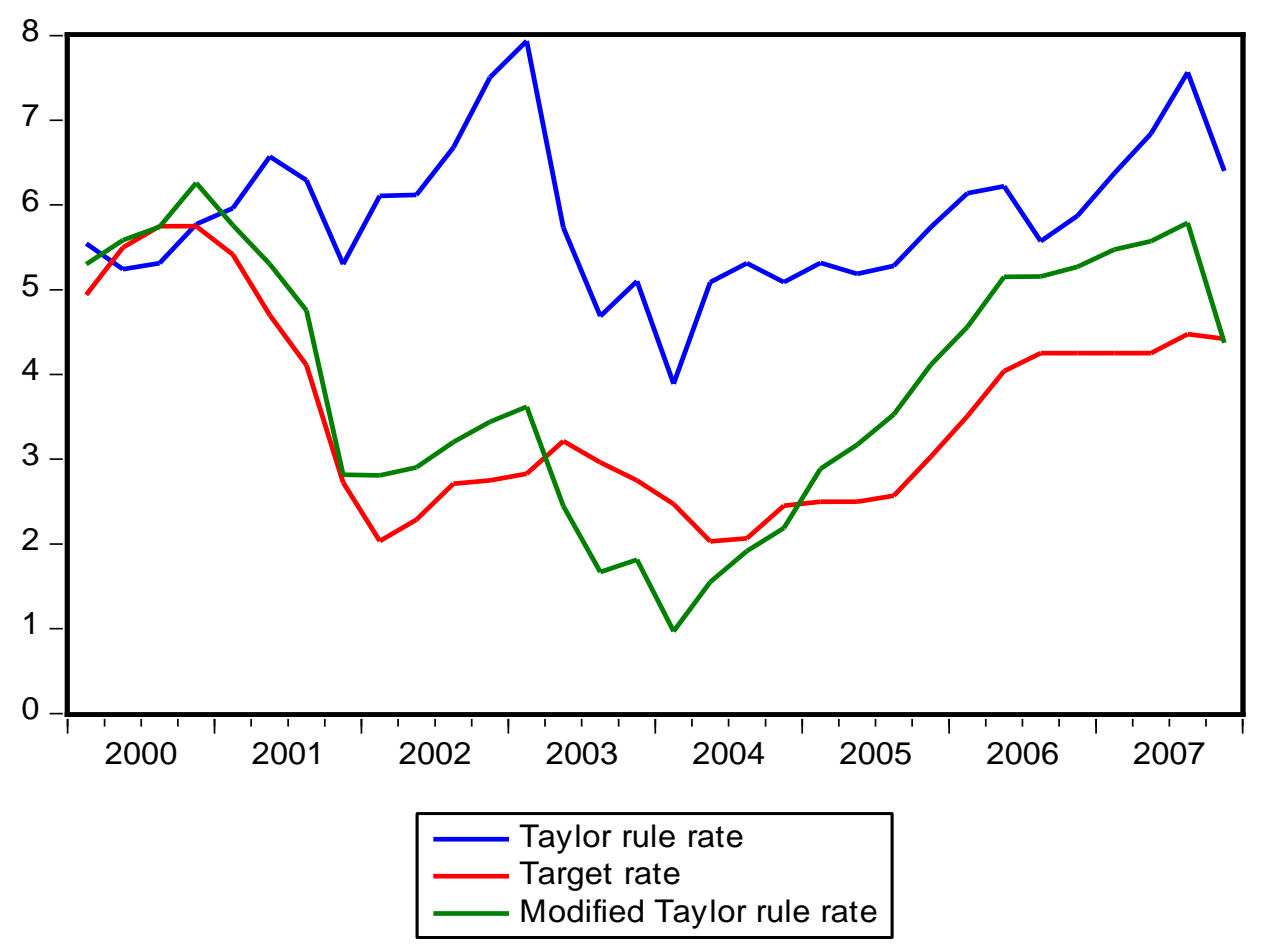

Source: See Appendix 1.

Figure 6. Real Policy Rates in Canada and the United States

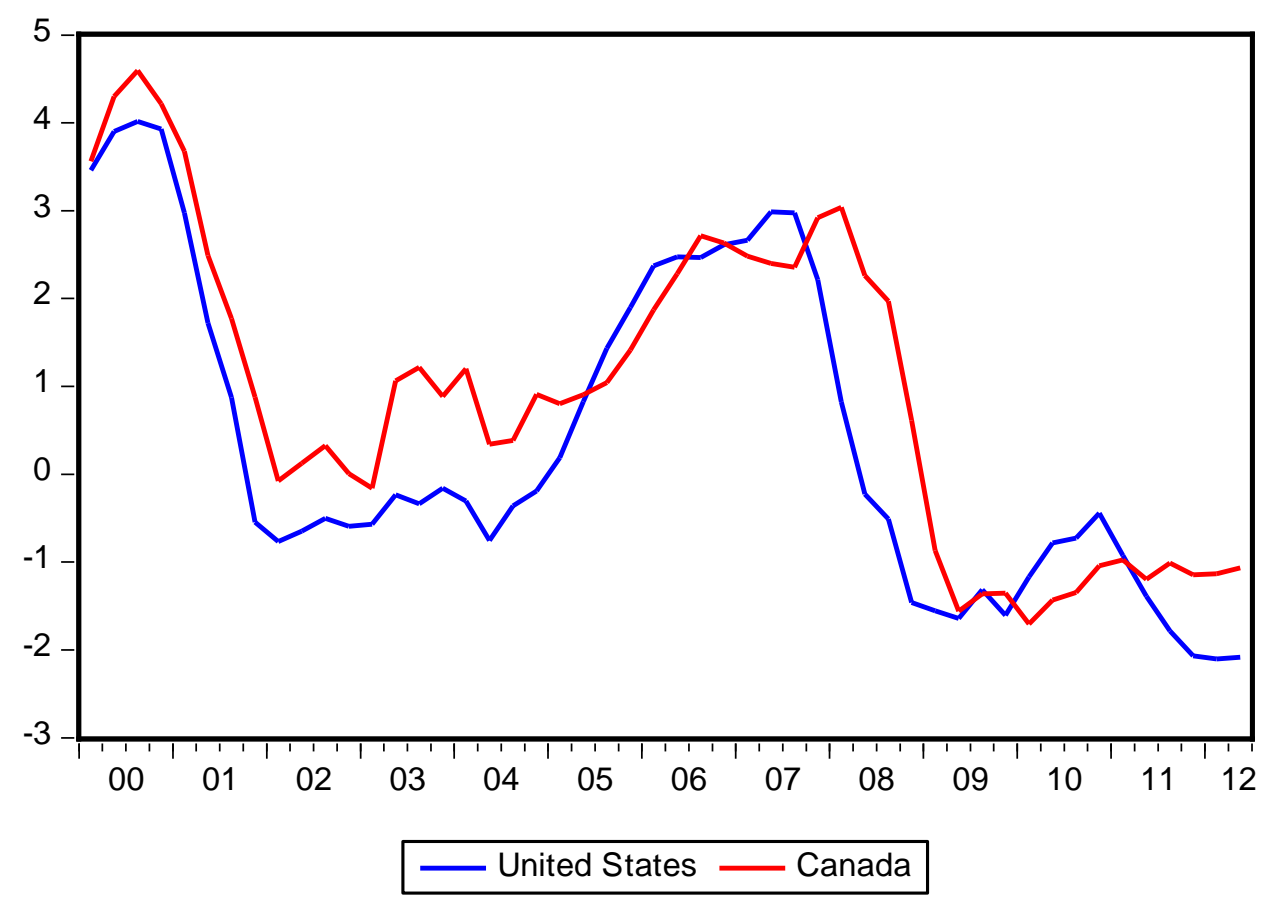

Source: See Appendix 1. 
Figure 7. House Prices in Canada and the United States

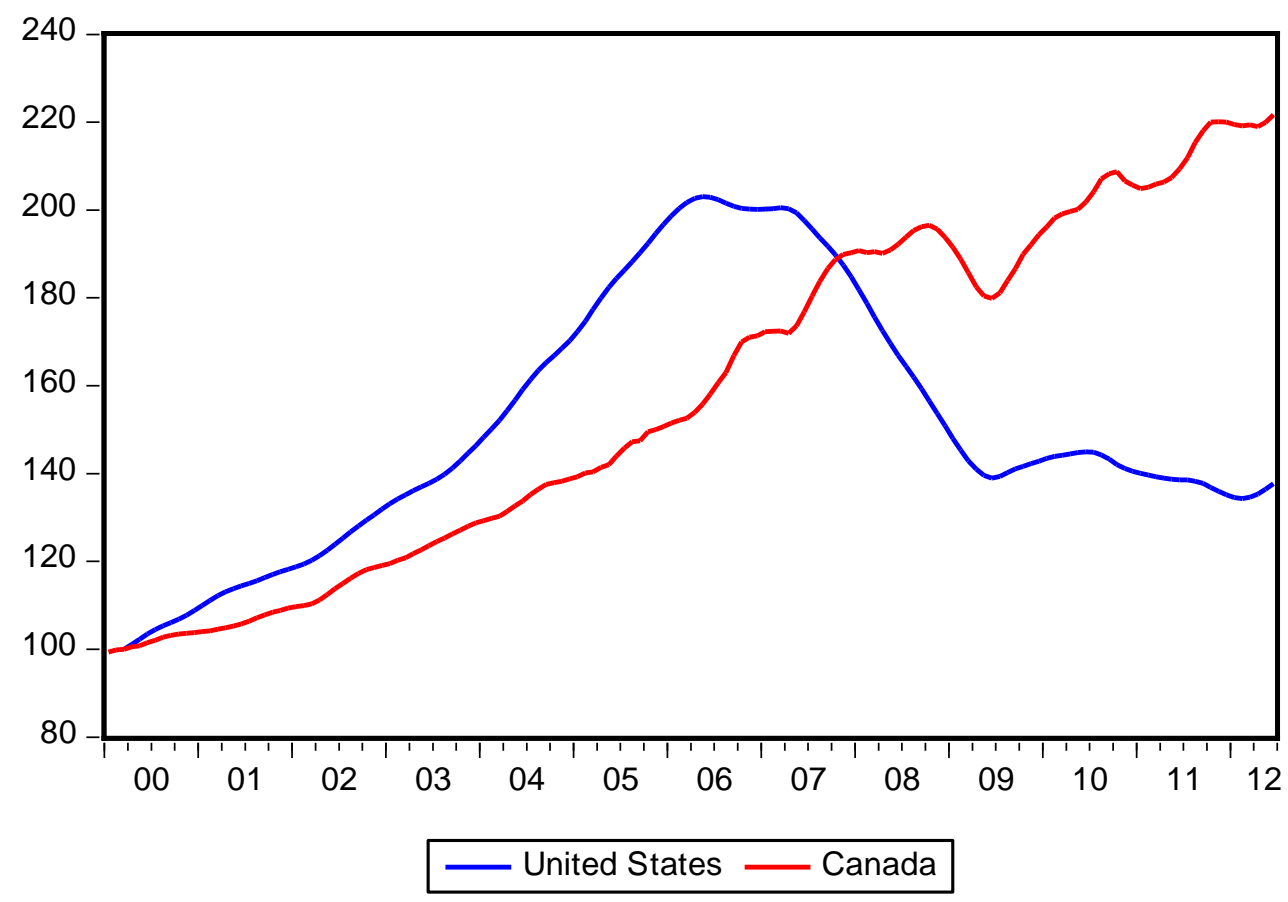

Source: See Appendix 1.

Figure 8. The U.S. Short-Term Interest Rates

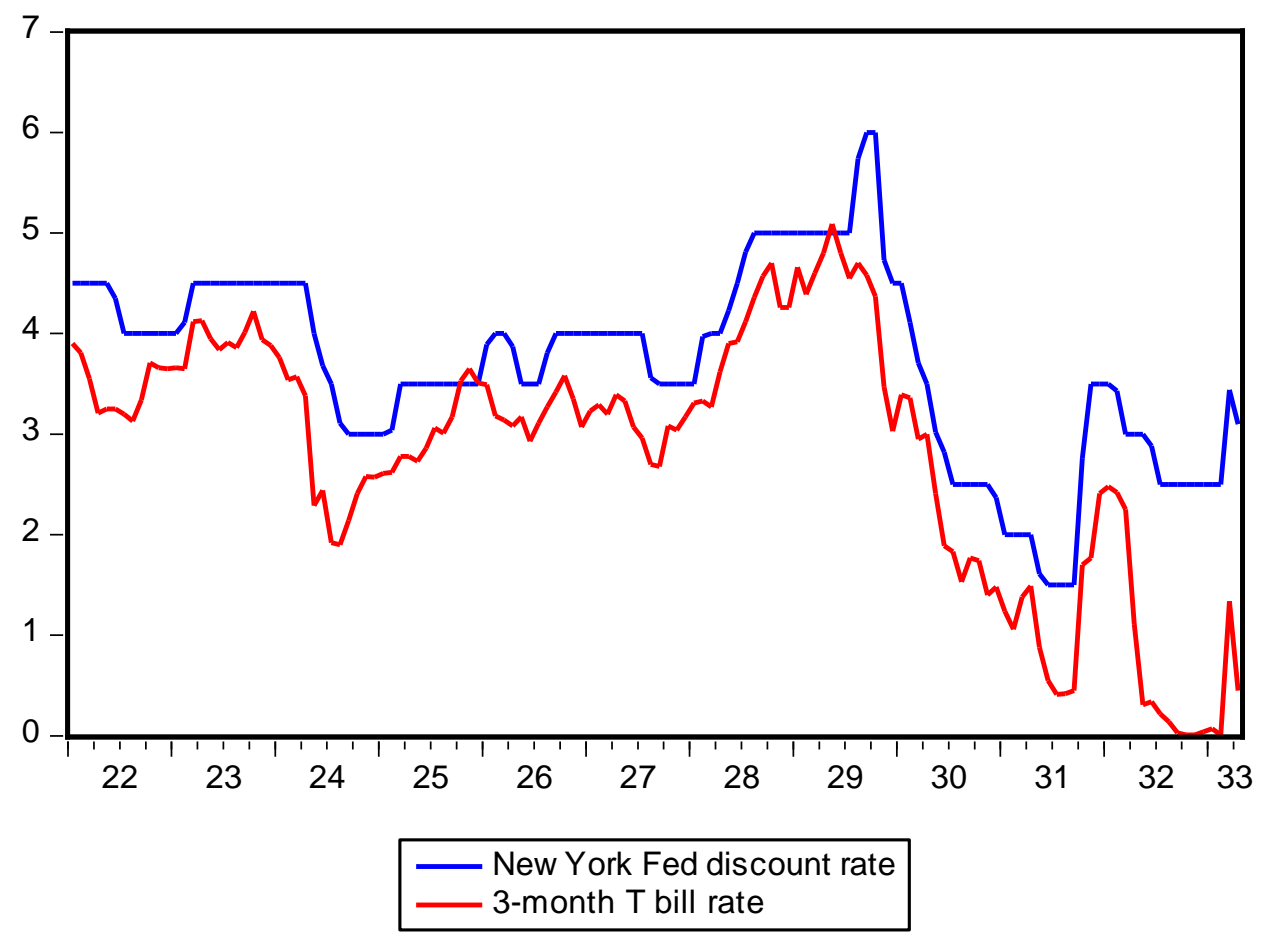

Source: See Appendix 1. 
Figure 9. The Canadian Advance Rate and the New York Fed Discount Rate

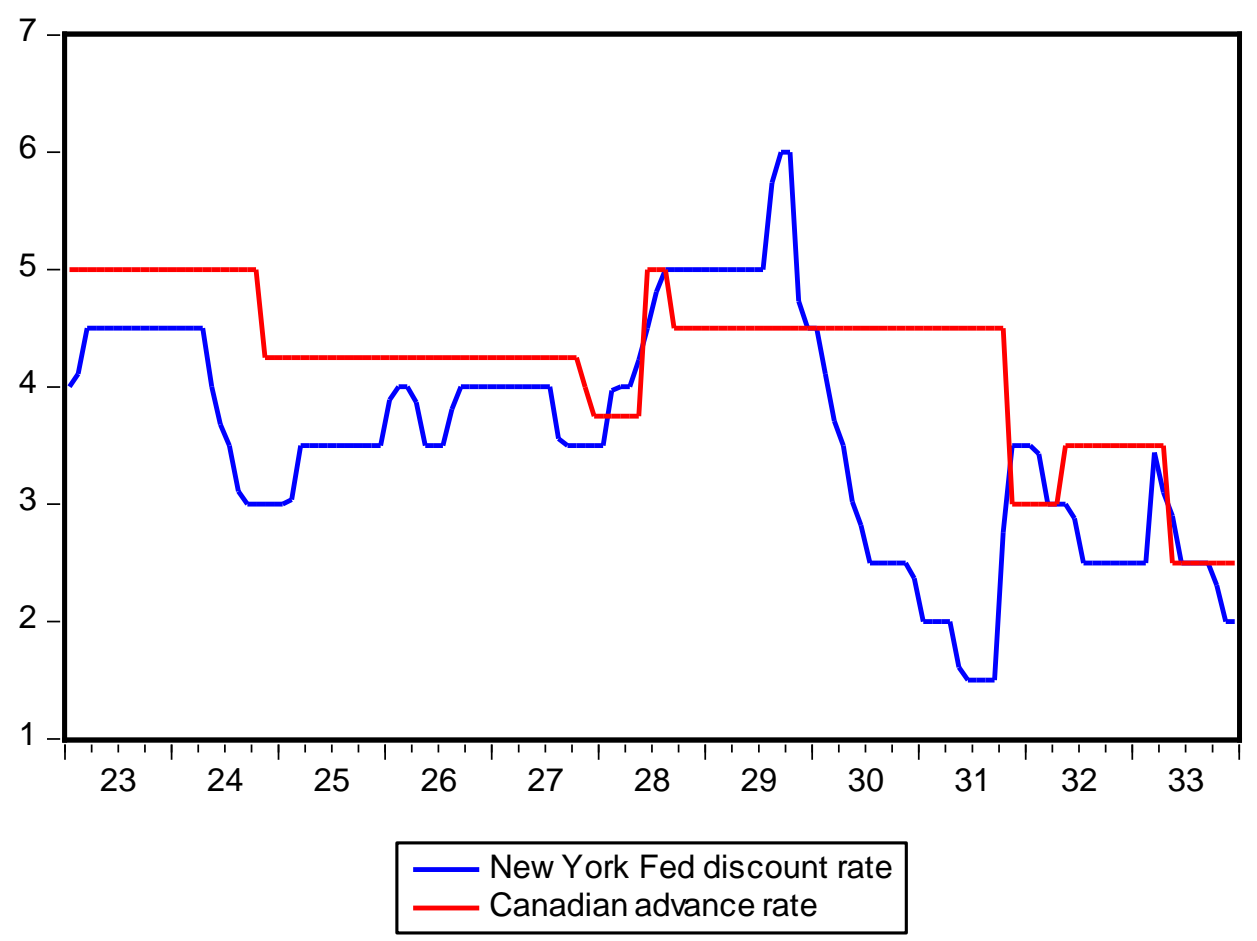

Source: See Appendix 1.

Figure 10. Detrended Industrial Production in Canada and the United States

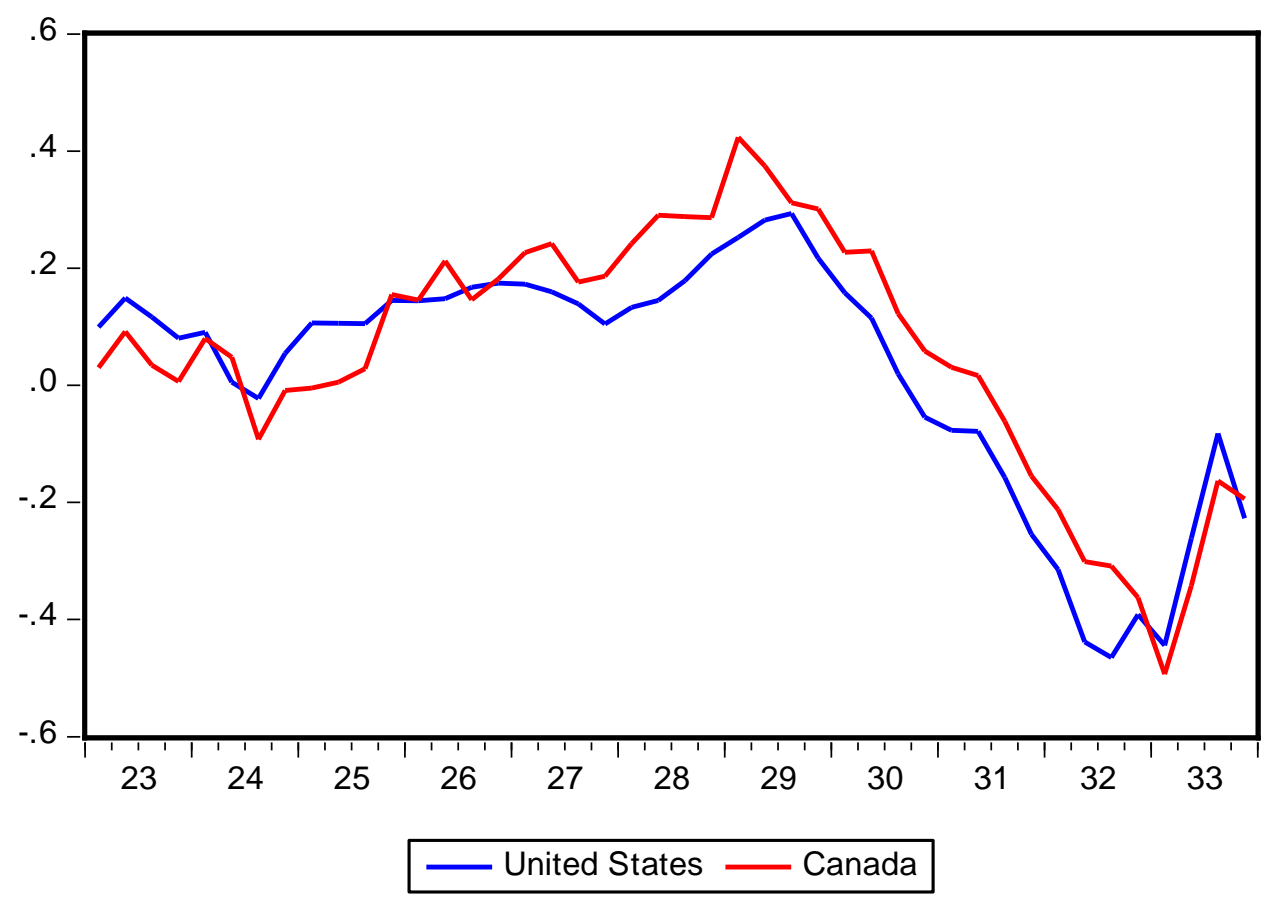

Source: See Appendix 1. 
Figure 11. 4-Quarter CPI Inflation in Canada and the United States

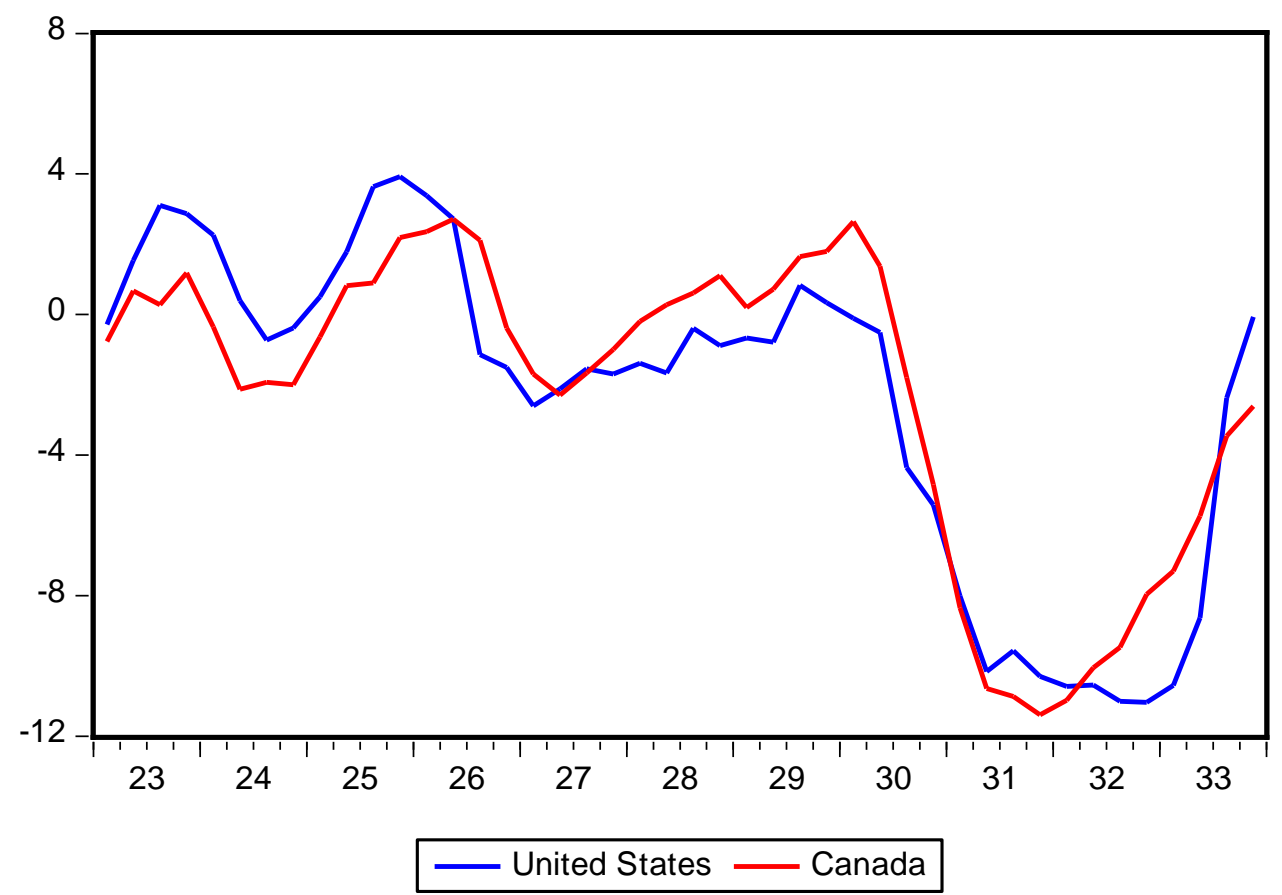

Source: See Appendix 1.

Figure 12. Stock Prices in Canada and the United States

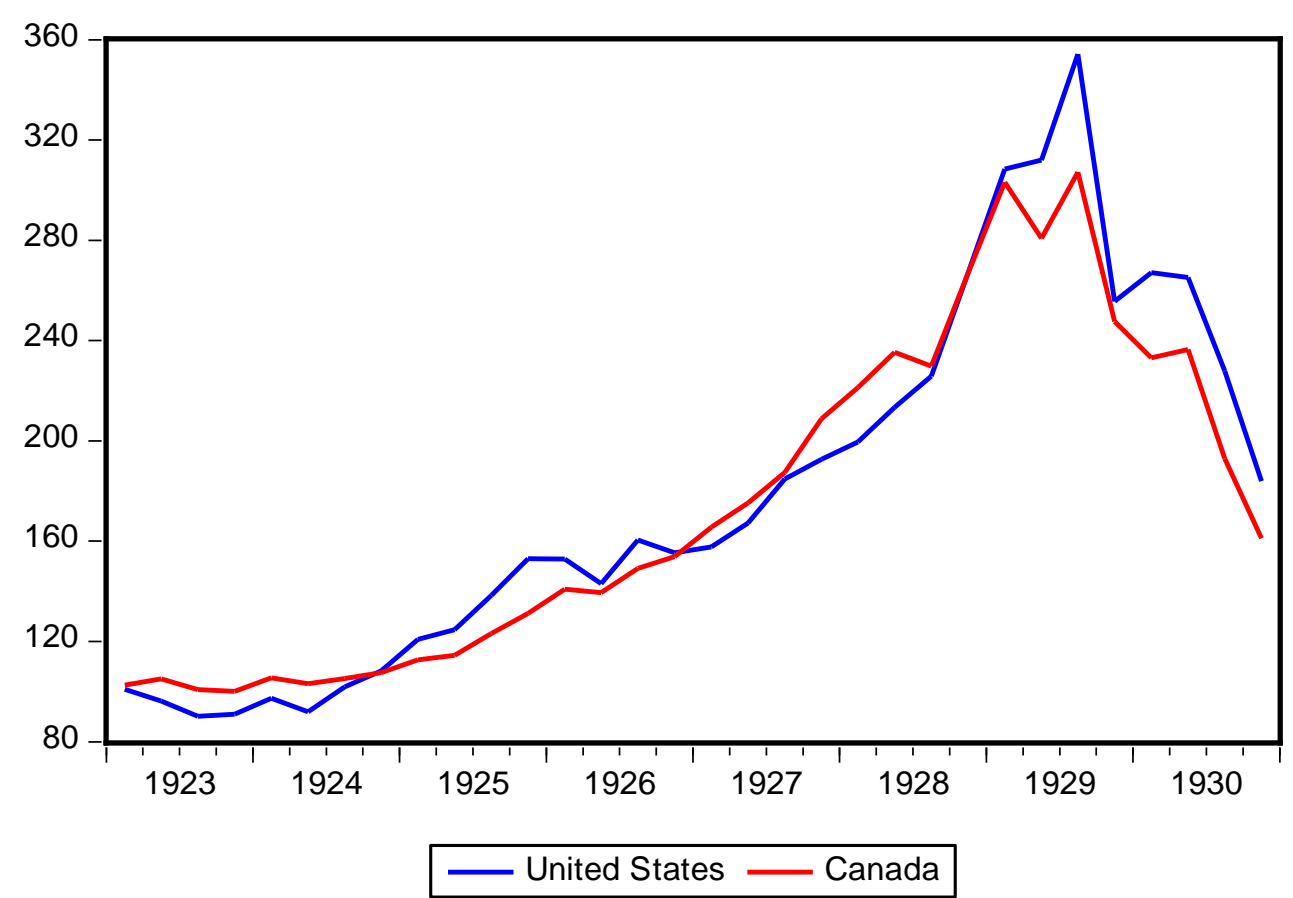

Source: See Appendix 1. 
Figure 13. The Canadian-U.S. Dollar Exchange Rate

Exchange rate (US\$/C\$)

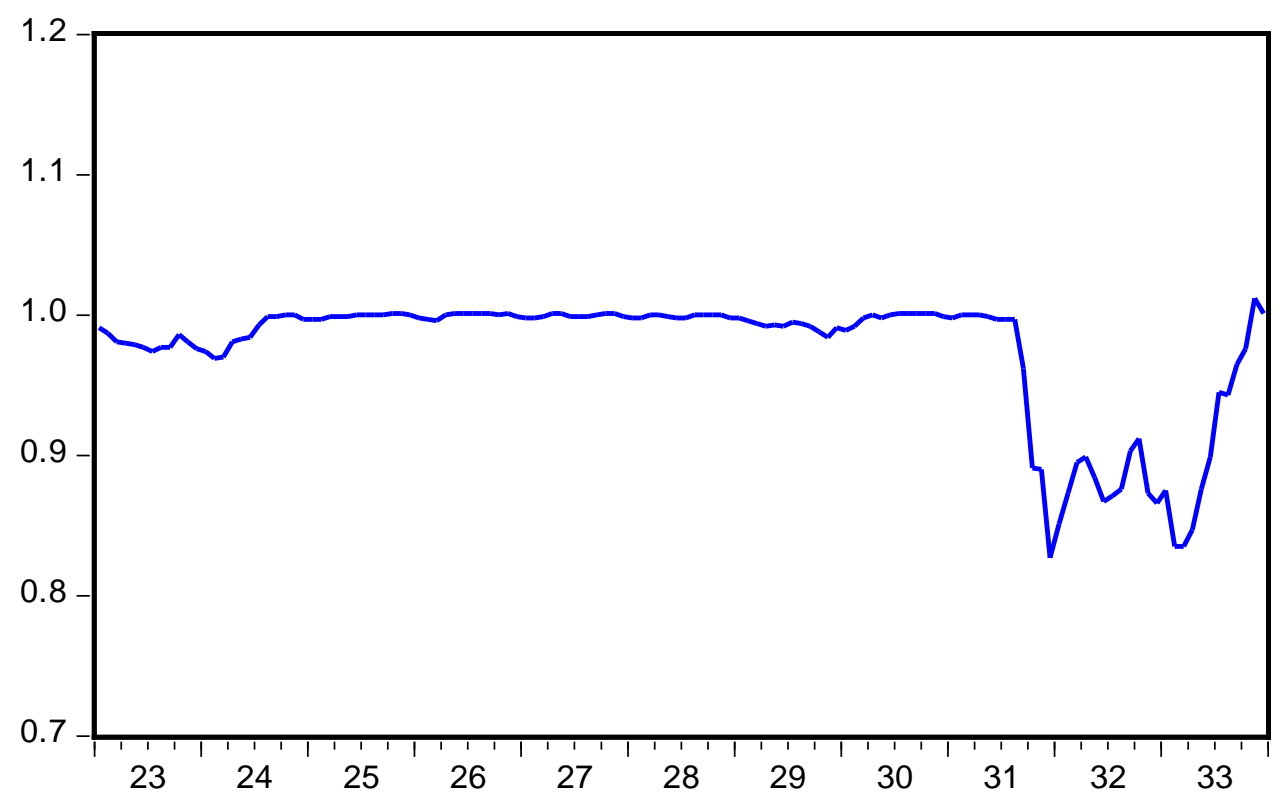

Source: See Appendix 1.

Figure 14. Real Policy Rates in Canada and the U.S, During the Great Depression

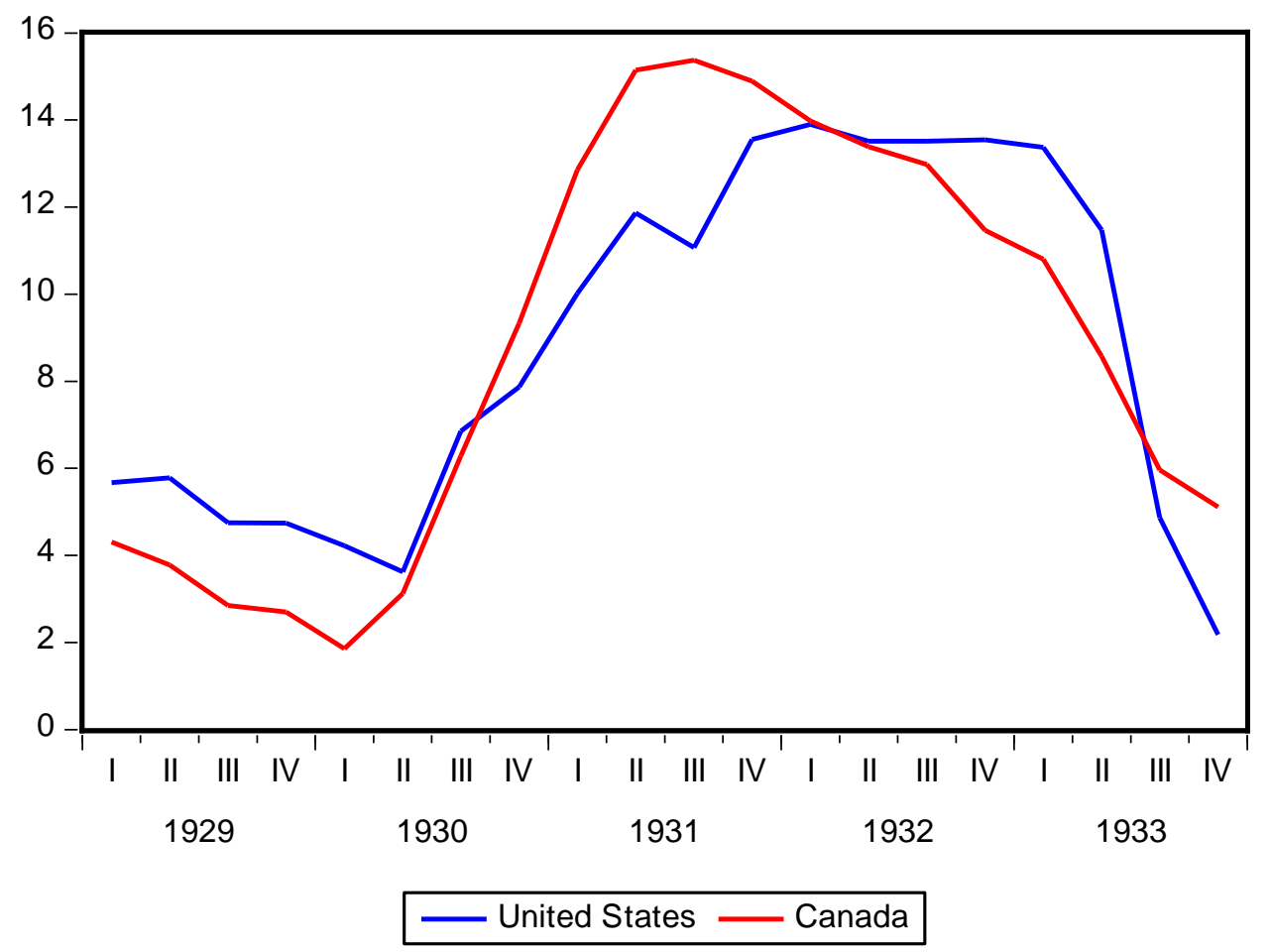

Source: See Appendix 1. 


\section{Appendix 1. Description and Sources of Data}

\section{U.S. Data}

For the recent period, quarterly data for actual and potential real GDP, and monthly data for core CPI index, US Federal Funds Rate and house prices were obtained from Federal Reserve Bank of St. Louis Database (FRED). Potential real GDP data are based on CBO estimates; core CPI index (all items less food and energy) is seasonally adjusted; and house prices represent S\&P Case-Shiller 20 city (seasonally adjusted ) home price index. This index was converted to a 3month moving average to make it comparable with the Canadian index discusses below. Output gap was calculated as the log difference between actual and potential real GDP (multiplied by 100). After converting monthly data to quarterly frequency, 4-quarter core CPI inflation was calculated as the log difference between CPI in the current and current minus 4 quarters (multiplied by 100).

For the early period, monthly data for New York Fed Discount Rate, 3-month T- Bill Rate, CPI index, and stock prices are from NBER Macrohistory Database, and for industrial production (seasonally adjusted) are from FRED. The 3-month T-Bill Rate represents average of daily figures for US Treasury 3-6 month notes and certificates. CPI index in the early period was called the cost of living index. To calculate an output gap measure based on industrial production data, this data were converted to quarterly frequency, a linear trend was fitted to quarterly data from 1919Q1 to 1933Q4, and the gap was calculated as the log difference between actual and trend levels (multiplied by 100). 4-quarter CPI inflation was calculated the same way as in the recent period. 


\section{Canadian Data}

For the recent period, monthly data for the core CPI index and the Canadian Target Rate, and the quarterly data for the output gap are from Bank of Canada. Data for Canadian house prices represent Teranet bank 11-city house price index (3-month moving average). 4-quater inflation rate index is calculated the same way as the US index.

For the early period, monthly data for CPI index are from Dominion Bureau of Statistics, Cost of Living Index Numbers for Canada, 1913-46; monthly data for industrial production and stock prices are from Dominion Bureau of Statistics, Economic Tendencies in Canada from 1919 to 1930, and Monthly Review of Business Statistics (various issues); monthly data (average of daily rates) for exchange rates (Canada-US and UK-US rates) are from Banking and Monetary Statistics, 1914-1941, International Financial Statistics; and Canadian Advance Rate data are form Shearer and Clark (1984). Industrial production based output gap and the 4-qurter inflation indexes are calculated the same way as the US indexes. 